\section{The Benefit of Being Second: An Event Study of Social Media Adoption}

Jeff Cummings

University of North Carolina Wilmington

Alan Dennis
Indiana University

Shawn O'Donoghue

University of Memphis

Kevin Cooney

Amazon, Inc.

\begin{abstract}
New technologies are continually being introduced and changing how firms interact with their customers. Because of this rapid rate of change, one of the most fundamental questions a firm faces is deciding whether, and when, to adopt a new technology. This is even more challenging for public social media technologies (e.g., Facebook) that can be adopted by all competitors in a marketplace. Our study uses event study analysis to investigate the impact on firm value of adopting two social media technologies: Facebook and Twitter. We find increased value following the adoption of both Facebook and Twitter, but not all firms experienced an increase in value. Interestingly, it was the second wave of adopters (i.e., those that quickly followed the initial adopters) that benefited more than first movers or later adopters. This study sheds light on strategies for companies considering if (and when) they should invest in new social media technologies and other technologies of the same form - direct-to-consumer technologies and apps offered by a third party that are open to all competitors.
\end{abstract}

Keywords: Social Media; Social Networking Sites (SNS); Facebook; Twitter; Diffusion of Innovations; Event Study.

\section{Introduction}

The speed at which technology innovations are being introduced continues at an exceptional rate. New technologies are constantly changing not only how individuals interact with each other but also how firms interact with customers (Trusov et al., 2009). Because of this, innovation has become a core challenge for many organizations-with one of the most challenging questions being the decision of whether and when to innovate (Swanson \& Ramiller, 2004). The decision to innovate often comes down to the strategic business value provided by the new technology (Oh \& Pinsonneault, 2007). Value often accrues to those first adopting a new technology, particularly a technology that can provide a hard-tocopy competitive advantage (Barney, 1991; Santhanam \& Hartono, 2003), and as such, often leads to increased firm value (Bharadwaj, 2000; Melville et al., 2004). However, are there advantages to adopting public direct-to-consumer technologies such as social media?

Studies typically focus on technologies that offer hard-to-copy competitive advantages (e.g., Subramani \& Walden, 2001), or packages designed to revise internal business processes, hidden from a competitor's view (e.g., ERP adoptions (see Ranganathan \& Brown, 2006)). In contrast, public 
technologies operated by third party vendors (e.g., social media) are viewable by all competitors; they are inherently open to copying and thus may offer limited competitive advantage (Barney, 1991). Thus, the challenge is determining whether these technologies have value to the firm, and if so, when to adopt them. These technologies may be more dependent on network externalities, i.e. how many external users are engaging with the technology. Prior theory would suggest that if there are competitive advantages, they are fleeting, and thus, first movers might be able to capture some initial value while following firms see little value (Kerin et al., 1992; Lieberman \& Montgomery, 1998). However, social media technologies may experience network effects, in that their usefulness increases as more people use them (Trusov et al., 2009), so being a first mover may not be the optimal strategy.

Our research examines whether the adoption of a public social media has an impact on the market value of firms and whether those impacts are affected by the timing of adoption. Specifically, we use an event study methodology to analyze changes in firm value following a firm's adoption of two public social networking sites (SNSs): Facebook and Twitter. Many firms are adopting SNSs because they provide new communication channels to interact with customers (Dong \& Wu, 2015; Rosen \& Phillips, 2011). Facebook has over 1 billion users ${ }^{1}$ and Twitter has more than 320 million. $^{2}$ Furthermore, we address a firm's strategic approach to social technologies, which has been suggested as a priority for future strategic information systems research (Merali et al., 2012).

\section{Background and Hypotheses}

Social media enable individuals to interact in ways not seen before (Boyd \& Ellison, 2007) which has led organizations to consider social media as a means of engaging customers (Hale, 2010; Holzner, 2009). One social media technology having a large impact on the firm-customer relationship are SNSs such as Facebook and Twitter. SNSs are web-based services enabling individuals to create an online persona (e.g., Facebook profile or Twitter account), create/maintain connections (e.g., friends or followers), and connect/socialize with others (Boyd \& Ellison, 2007; Gnyawali et al., 2010). These sites offer individuals and firms a means to present themselves in a digital format, enabling them to provide details concerning themselves and develop a network of relationships (Ellison et al., 2007).

For firms, corporate profiles (or "fan" pages) enable individuals to engage with firms through the SNS (Rosen \& Phillips, 2011) and provide value to the firm with an additional customer communication channel
(Dong \& Wu, 2015; Xia \& Zhang, 2010). Users can "like" (Facebook) or "follow" (Twitter) firms creating a new line of communication for firms to conduct targeted marketing to new and existing customers (Holzner, 2009). This enables firms to gain exposure to consumers and create specific content for a targeted market (Hale, 2010). The goal of the current study is to evaluate whether a firm engaging in a public SNS influences firm value. Specifically, we examine the initial entry of consumer-facing firms into SNSs and the impact on the firm value.

Some researchers have argued there is minimal cost to adopting public SNS technologies (e.g. Facebook or Twitter) (Trusov et al., 2009) which suggests that all organizations should adopt SNSs regardless of business value. However, prior research on adoption and implementation concludes that while the initial cost to adopt may be minor, there are often substantial ongoing costs to operate that technology (Goode, 2005; Goode \& Stevens, 2000; Irani et al., 2006). Today, more than 75 percent of Fortune 500 firms have a social media presence with multiple staff, whose salaries range from $\$ 50,000$ to $\$ 110,000$ or more ${ }^{3}$ (Shih, 2015). Adoption of SNSs is often part of a larger strategic plan involving numerous employees implementing these strategies (Hansen \& Kein, 2015). In fact, many firms spend \$5-10 million a year on social media, both managing external social media sites and advertising (Mohr, 2012; Sweeney, 2012). Thus, while the cost of creating a SNS page for an individual person is minimal, Fortune 500 firms adopt SNSs knowing there are a variety of large initial and ongoing costs, including staff to design/implement the site, monitor customer feedback, create/manage online marketing campaigns, and site maintenance/updating (Mohr, 2012; Sweeney, 2012).

\section{Business Value of Innovation}

Innovation can be one of the most important sources of competitive advantage creating firm value (Dess, 2000; Tushman \& O'Reilly, 1996). This is why innovation adoption continues to be a prominent topic in IS research with various theories linking organizational innovation adoption to business value (Melville et al., 2004). Research has examined a range of topics from the approach of innovation adoption (Choi \& Chang, 2009; Swanson \& Ramiller, 2004 ) to the diffusion of these innovations (Fichman, 2004; Wejnert, 2002). One prominent theoretical lens is the resource-based view (RBV) of the firm (Bharadwaj, 2000; Melville et al., 2004).

Within IS research, RBV has been used to understand the relationship between innovation as a resource for firms wanting to increase business value (Bharadwaj, 2000; Melville et al., 2004; Teo et al., 
2016). RBV suggests the value of an innovation can be assessed by examining the competitive advantage achieved through the use or adoption of that innovative resource (Barney, 1991). Thus, to understand the link between business value and innovation adoption, researchers have examined technological capabilities and the increased utility from using those resources (Wade \& Hulland, 2004). One approach is to examine resources as marketingbased assets (Srivastava et al., 2001), which is particularly appropriate in our case because SNSs are used to manage external relationships with customers (Bharadwaj, 2000; Srivastava et al., 1998). These SNS resources create customer value leading to a competitive advantage over other firms that creates value for the firm (Orlikowski \& Lacono, 2001; Srivastava et al., 2001).

Research suggests that the business value of market-based assets such as SNSs can be assessed using shareholder value (Srivastava et al., 2001). Srivastava et. al. (1998) provide a framework that examines four distinct mechanisms by which these assets may create shareholder value: increases in cash flows, acceleration of cash flows, reduction in risks associated with cash flows (i.e. vulnerability and volatility), and increases in expected cash flow from future business. Table 1 below provides a description of each of the mechanisms with an example of how a SNS may act as a market-based asset.

Each of these four mechanisms has the potential to create business value; any one mechanism may be sufficient to create enough business value to make SNS investment profitable (Srivastava et al., 1998). We can assume that firms are leveraging SNSs via one or all of the mechanisms to create value. However, it is difficult to know which of these a firm intends to pursue; therefore, this research does not focus on identifying the mechanism used. Instead, the focus is on the overall impact on firm value when that firm first chooses to adopt a SNS. We expect this value to be reflected through positive investor reaction and in turn, increase business value. This positive reaction will be represented as a positive shift in stock price, or a positive abnormal return, i.e., a return in excess of what the firm would normally expect. If SNS do increase business value, then a positive abnormal return from SNS investment would occur on the date a firm adopts the SNS technology. Such an abnormal return is a gauge of business value by firms experiencing above average returns (Peteraf, 1993; Schoemaker, 1990). We argue that the adoption of a new public SNS will lead to increased firm value as seen through positive abnormal returns. Thus:

Hypothesis 1a (H1a): Firms will experience positive abnormal returns following the adoption of Facebook.

Hypothesis 1b (H1b): Firms will experience positive abnormal returns following the adoption of Twitter.

Table 1. Market-based Asset Mechanisms (Based on Cash Flows)

\begin{tabular}{|l|l|l|}
\hline Mechanism & Definition & SNS Example \\
\hline Increasing & $\begin{array}{l}\text { Strengthening customer relationships through } \\
\text { collaboration (Srivastava et al., 1998). }\end{array}$ & $\begin{array}{l}\text { Starbucks introduced an idea blog to encourage customers to } \\
\text { share ideas. "My Starbucks Idea" generated over 70,000 ideas } \\
\text { with many being implemented (Dong \& Wu, 2015; My } \\
\text { Starbucks Idea, 2009). }\end{array}$ \\
\hline Accelerating & $\begin{array}{l}\text { Marketing activities, such as co-marketing } \\
\text { partnerships, aimed at increasing marketplace } \\
\text { response is one potential accelerator of cash } \\
\text { flows (Doyle, 2000; Keller, 1993). }\end{array}$ & $\begin{array}{l}\text { Marketing campaigns and promotions targeting SNS "fans" or } \\
\text { "followers." For example, Starbucks actively engages its } \\
\text { customers through Twitter by asking them for feedback while } \\
\text { publicizing deals. }\end{array}$ \\
\hline Risk reduction & $\begin{array}{l}\text { Lower the vulnerability and volatility of cash flows } \\
\text { (Srivastava et al., 1998) which can be done by } \\
\text { increasing loyalty (c.f. Kumar \& Shah, 2004). }\end{array}$ & $\begin{array}{l}\text { Companies give additional perks for those Facebook users } \\
\text { who "Like" a company (e.g., Toys "R" Us regularly has } \\
\text { promotions providing giveaways to new "fans" of the site) and } \\
\text { SNS-only promotions (e.g., JetBlue offers Twitter only deals } \\
\text { called Cheeps for last-minute discount fares (Jones, 2009)). }\end{array}$ \\
\hline $\begin{array}{l}\text { Future } \\
\text { Business }\end{array}$ & $\begin{array}{l}\text { Expected future cash flows can come from } \\
\text { existing customers (e.g., buying additional } \\
\text { products) or through referral to new customers } \\
\text { (Srivastava et al., 1998). }\end{array}$ & $\begin{array}{l}\text { An online presence in SNSs allows firms to expand by } \\
\text { reaching new customers and new segments without traditional } \\
\text { geographical or time limitations (Evans \& Wurster, 1997). }\end{array}$ \\
\hline
\end{tabular}




\section{The Timing of Technology Adoption}

While the first question many organizations face is whether or not to innovate, the question that most often follows is when to innovate (Swanson \& Ramiller, 2004). Some firms choose to be the first to adopt while others wait. Under the Diffusion of Innovations (DOI) theory, Rogers (1995) suggests technology adoption moves through five stages (in order from earliest adopters to later adopters): innovators, early adopters, early majority, late majority, and laggards. DOI examines the process by which an innovation spreads throughout multiple firms by understanding the point of adoption in an innovation's lifecycle (Choudhury \& Karahanna, 2008; Jeyaraj et al., 2006). That is, at which stage during the adoption process does a firm decide to adopt a new technology (Crawford \& Di Benedetto, 2008)? DOI suggests that the rate of diffusion is initially slow with those firms that are more inclined to take risks adopting first. Although SNSs may not provide a sustainable competitive advantage (i.e. not rare, unique, or inimitable (Barney, 1991)), these firms gain an initial competitive advantage by choosing to innovate first (Kettinger et al., 1994; Wade \& Hulland, 2004). As adoption continues, critical mass is reached where a large number of firms have chosen to adopt (Rogers, 1995). At this point, there would be a minimal competitive advantage to adopting the innovation (Barney, 1991). Thus, time is a key component affecting the initial competitive advantage received from adopting a technology; firms that adopt in the early stages may receive an initial competitive advantage compared to those firms that adopt later (Kettinger et al., 1994).

The link between technology and competitive advantage has led to a greater disparity between the leaders and laggards in various industries (McAfee \& Brynjolfsson, 2008). While McAfee and Brynjolfsson (2008) find this to be fleeting, there is evidence to show that first movers and early adopters tend to reap the most benefits (e.g. increased shareholder wealth) compared to laggards adopting new technology. For example, Lee et al. (2000) found timing to have a significant impact on increasing shareholder wealth. Their study found that those firms early in the adoption process (i.e. first and second movers) saw increased shareholder wealth while late movers did not see any significant increases. Furthermore, many firms later in the adoption cycle tend to approach the decision from a "me too" mentality in which adoption is not for a competitive advantage but more to maintain the same level of competitiveness in the market (Fiol \& O'Connor, 2003; Rosenkopf \& Abrahamson, 1999). Thus, to understand timing and adoption, our research examines those companies in the first half of a technological lifecycle who are more likely to receive an initial competitive advantage, as the technology may still be new or unique. Innovators and early adopters are the opinion leaders that influence those choosing to adopt later in the lifecycle (early majority, late majority, laggards) (Rogers, 1995). Thus, we focus on the innovators choosing to adopt first (i.e. first movers) followed by the early adopters (i.e. fast followers). To understand if subsequent adopters receive an initial competitive advantage resulting in abnormal returns, early majority is included in the analysis. Each group analyzed is discussed in more detail below.

Firms choosing to adopt first (i.e. innovators) would benefit most by receiving first mover advantage (Suarez \& Lanzolla, 2007). SNSs have continued to evolve as a technology while gaining market space suggesting that a first mover advantage can exist in this environment, challenging later entrants to overtake first movers (Suarez \& Lanzolla, 2007). Furthermore, within certain industries, the first mover might have a greater advantage due to market segment (Carpenter \& Nakamoto, 1989). For example, a consumer-focused firm might see a significant first mover advantage over non-consumerfocused firms. These firms create business value by providing a unique service to consumers while building strong customer relationships.

Alternatively, one may suggest that fast followers gain a greater benefit by waiting. Prior research would suggest these firms are making a mindful decision (Swanson \& Ramiller, 2004) because technology is not always used in the way developers initially intend it to be used and may take time to build social structures (DeSanctis \& Poole, 1994). Business value from a specific technology may not always be obvious in the early stages of adoption and customer preference may have a significant effect on the success of those innovators choosing to adopt (Carpenter \& Nakamoto, 1989). In the case of SNSs, the original intent of most was for individuals to create/maintain relationships. When firms entered, the social structure of the technology changed, and the users' preference of using these sites for personal relationships had to change and adapt to the new environment. Thus, the business value for firms may not appear early in the life of these technologies while these social structures are in flux.

Finally, the next group, early majority, may not see any abnormal returns. During this part of the lifecycle, firms must consider timing of entry and the impact of this decision. These firms adopt the technology at the stage in which it is more widely accepted with social structures in place. At this point, a firm's decision to enter may be based on a careful and mindful strategy of deliberately eschewing new 
innovations until they have been proven in the marketplace. Conversely, it may be a "me too" approach of following the bandwagon associated with new technologies (Fiol \& O'Connor, 2003; Lyytinen \& Newman, 2008); as Dilbert's Pointy-Haired Boss notes: "Everybody's doing it. We'd better jump under the bandwagon before the train leaves the station!" (See http://dilbert.com/strip/1994-02-28). In the subsequent paragraphs, we examine timing of adoption for first movers (i.e. innovators) and fast followers (i.e. early adopters) to understand creation of business value for firms compared to others (i.e. early majority) who choose to adopt later (i.e. bandwagon phenomenon).

\section{Innovators and First Mover Advantage}

First mover advantage has been researched extensively to understand the ideal entry point into new market space. Research has shown clear advantages to being the first mover in a market and in general, being the first provides greater benefits over those moving later, particularly when firms can easily copy each other (Lieberman \& Montgomery, 1998; VanderWerf \& Mahon, 1997). First mover advantage theory argues that proactive firms entering a market space first may benefit from a temporal competitive advantage (Suarez \& Lanzolla, 2007). By entering at the beginning, first movers gain consumer confidence and trust (e.g. the established firm in the market), which can continue even as new entrants emerge and the overall market grows (Mellahi \& Johnson, 2000). This is determined by the skill and resources of the firm entering the market and their willingness to take a risk for a higher return (Kalyanaram et al., 1995). First movers learn more quickly and can leverage this knowledge to better develop their skills and resources to stay one step ahead of those who follow (Mellahi \& Johnson, 2000). Thus, new market innovators (or first movers) gain substantial advantages over those choosing to adopt later (e.g. early adopters or early majority). This may be particularly true for public SNS technologies whose use can easily be copied by competitors; competitive advantage is fleeting because firms that follow quickly copy the first mover.

Research on IT adoption is generally consistent with prior marketing research in showing that those choosing to adopt first receive the most benefit (e.g., pioneering advantage) from a newly introduced technology (Carpenter \& Nakamoto, 1989; Kerin et al., 1992; Lieberman \& Montgomery, 1988). For example, firms innovating first in Internet-based consumer services develop strong, emotional ties with their users while establishing sustainable value for their consumers (Liang et al., 2009). These firms often have a vision of what consumers desire in a technology (e.g. SNS) and exceed what later entrants have to offer. Given potential benefits of an innovator, we hypothesize that the first moving innovators will have higher abnormal returns compared to those adopting later in the lifecycle (i.e. the early majority). Thus,

Hypothesis 2a $(\mathrm{H} 2 \mathrm{a})$ : Firms in the innovator group will experience greater abnormal returns from Facebook adoption than those in the early majority group.

Hypothesis $2 b(\mathrm{H} 2 \mathrm{~b})$ : Firms in the innovator group will experience greater abnormal returns from Twitter adoption than those in the early majority group.

\section{Fast Followers and Mindful Decisions}

Contrary to first mover advantage, some suggest fast followers (i.e. early adopters) who enter the market shortly after the first movers (i.e. innovators) also benefit from early adoption (Hidding \& Williams, 2003). Swanson and Ramiller (2004) suggest timing plays a role in adoption with first movers needing to be especially mindful, as little is known about applicability of the innovation. Alternatively, firms who choose to adopt later in the lifecycle (e.g. early majority) may mindlessly adopt based on the increased popularity (i.e. bandwagon phenomenon) (Abrahamson, 1991; Abrahamson \& Fairchild, 1999). Thus, timing plays an integral role for a firm's decision to innovate either mindfully or mindlessly.

A fast follower strategy may be appropriate for public SNS technologies that have network effects. Fast followers (i.e. second movers) benefit from decreased risk compared to first movers because more is known about the technology, new social structures from the innovation have stabilized, and a larger network of consumers are using it (Poletti et al., 2011). While innovators are the first to enter the market, fast followers make a mindful decision to enter the market, which involves careful evaluation of the technology (Swanson \& Ramiller, 2004). Fast followers adopt the technology once it has become more stable and has been demonstrated to be useful (Hoppe, 2000; Shankar et al., 1998). For example, Yahoo was an early search engine widely used throughout the World Wide Web, yet Google followed and overtook Yahoo. Google was able to capture consumers who were looking for a better alternative to the available search engine (i.e. Yahoo) (Shankar \& Carpenter, 2012).

Public SNS technologies are different from many other IT innovations adopted by firms because they are designed by third parties and used by the general public. An individual firm has less control over the technology. SNSs were originally designed for one 
purpose, a medium for social interactions with an individual's friends, while firms have adapted them for another purpose, to interact with current and potential customers. This change to the social structures takes time, which is one reason why a fast follower who enters the market later may be more successful.

A second reason fast followers may experience an increase in firm value may be due to the size of the network of users (Kauffman et al., 2000; Schilling, 2002; Shapiro \& Varian, 1999). First movers may have moved too soon, before the network of users is large enough to provide substantial value (Poletti et al., 2011). By waiting until the network is larger, fast followers are better able to more quickly capitalize on the value of the technology.

Under DOI, fast followers are categorized as early adopters (those immediately following innovators) and will also see increased abnormal returns compared to those adopting in a later stage of the diffusion curve (i.e. the early majority stage) due to a mindful decision to adopt a technology before being influenced by social pressures to adopt (or bandwagon phenomenon). Thus:

Hypothesis $3 a(\mathrm{H} 3 a)$ : Firms in the early adopter group will experience greater abnormal returns from Facebook adoption than those in the early majority group.

Hypothesis $3 b(\mathrm{H} 3 b)$ : Firms in the early adopter group will experience greater abnormal returns from Twitter adoption than those in the early majority group.

\section{Methodology}

\section{Event Study Methodology}

An event study methodology is employed to evaluate the impact of adoption of SNSs on firm value using shareholder returns as a measure of performance (Day \& Fahey, 1988). When compared with other metrics of firm performance, such as market share and sales, firm stock returns are preferred because they are forward looking rather than backward looking (Day \& Fahey, 1988; Srivastava et al., 1998). A firm's stock price is the expected present value of all future cash flows, while market share and sales are calculated on past or realized cash flows.

Event studies have become a popular and accepted tool in information systems (Dewan \& Ren, 2007; Guan et al., 2006; Roztocki \& Weistroffer, 2009; Subramani \& Walden, 2001; Teo et al., 2016). They have been used to improve the understanding of various topics, such as online channel impacts on performance (Xia \& Zhang, 2010), e-commerce (Andoh-Baidoo et al., 2012), investments in IT (Roztocki \& Weistroffer, 2006), and IT failures
(Bharadwaj et al., 2009). Event studies have also been applied to the current context for understanding the impact of IT investments on the market value of the firm (Dehning et al., 2003; Dobija et al., 2012; Im et al., 2001).

The goal of an event study is to measure the effects of an economic event on the expected future value of the firm, revealed in its stock price. The firm's stock price reflects all public information about that firm, so only unexpected changes to that information can alter the price of the stock (Fama, 1970). As a result, the impact of an event can be measured by examining stock prices surrounding the event. Looking at stock price changes will signal the expectation of the future cash flow from SNSs. Assuming there is no other new information released at the same time as the SNS adoption, the economic impact of SNS adoption can be measured by examining the abnormal stock price changes surrounding that event.

Ultimately, the decision to adopt a SNS lies with management and therefore the timing of their decision to adopt might be a concern. That is, the choice of when to adopt the SNS might be endogenously determined by inside information which only management possesses. While the choice of when to adopt a SNS might be endogenous, this is not the purpose of the current study. We are not interested in the processes by which firms decide when to adopt but rather in testing how the stock market reacts once the firm does adopt. Our research question is investigating the stock market's reaction to new, novel information represented by SNS adoption.

\section{Data Acquisition}

Our target population for this study are firms in consumer-based industries as SNSs are consumeroriented technologies (Weber, 2009). This population includes firms which have adopted either Facebook or Twitter. To select our sampling frame, two criteria were considered. First, because our dependent variable is stock returns, only U.S. publically traded firms were used. Second, we selected only firms which operate within business-to-consumer (B to $\mathrm{C}$ ) industries because these firms would use public SNSs primarily to engage existing customers and to reach out to potential ones. The standard industrial classification (SIC) codes were used to screen firms to ones operating in these industries: automobiles, banking, beer, candy and soda, communications, computers, meals and restaurants, oil and gas, personal services, newspapers, retail, and transportation. To identify firms in these industries, all U.S. publically traded firms on all U.S. stock exchanges were obtained from CRSP via Wharton Research Data Services. Of over 6000 publically 
traded firms, 840 firms operated within a consumerbased industry (i.e. the SIC codes defined above) and were therefore identified as our sampling frame.

To discern whether investors perceive a firm's adoption of a SNS favorably, abnormal returns surrounding the adoption date of that technology are analyzed. Adoption dates for Facebook and Twitter were found in the following ways. Facebook does not provide the adoption date on fan pages, so the adoption date was established by using the first day the firm published its Facebook page. When first creating a Facebook page, the creator is asked some basic information such as uploading a photo, providing a website, and filling out an "About" section. Once any of this information is entered, it is posted to the Facebook page, marked with a date and made publically available. All posts since profile creation are available in Facebook. To identify the first public post date, we used an automatic user script. ${ }^{4}$ This would also be the first time the site is made publically available to SNS users.

Unlike Facebook, Twitter adoption dates can be obtained from Twitter. Twitter adoption dates were identified through the website www.whendidyoujointwitter.com. For any Twitter account, the website will return the date that the account was created. The website searches Twitter's public application programming interface (API), which runs in the background, and returns the date the account was created. ${ }^{5}$ This method works for any Twitter account created regardless of usage.

One concern may be that a profile was created, but not utilized until a later date. In other words, a firm creates an online presence within Facebook or Twitter and then never uses it. Some organizations acquire a new technology and then delay actual deployment to a later date (Fichman \& Kemerer, 1999). However, we argue that the creation date is appropriate for the "event date" for SNSs because companies adopt external marketing channels with a detailed plan for profile design and campaign strategies before the page is created (Mohr, 2012; Sweeney, 2012). To assess this assumption, we randomly selected 50 firms and found that all 50 made an initial posting on the creation date and followed this with one or more additional posts within a week or less. Thus, we conclude that our methods to identify the creation date are appropriate.

Another concern when using "creation date" for our event date may be how the market would react without a formal announcement of joining a SNS (e.g., a $10 \mathrm{~K}$ filing would not be required). Announcements about adopting Facebook and Twitter were found for some of the firms. While not all firms formally announced, all firms began using the
SNSs on the creation date. The efficient market hypothesis, which is the foundation of modern finance, argues that information spreads quickly and is reflected quickly in firm value (Fama, 1970). If for some unknown reason the efficient market hypothesis does not hold true, we would find no significant results; thus, our approach is conservative. Additionally, as described below, we conducted an analysis of confounding events (i.e. contaminating events that may impact stock price) for all of the firms, and removed those firms in which another event occurred near the creation date. Thus, we are confident that if we find an effect, it can only be attributed to the adoption of the SNS.

\section{Sample}

Of the 840 firms identified during data acquisition, 341 firms had a Facebook page, and 402 firms had a Twitter account (note: only the Twitter account created by the firm was used and not accounts created by the public). Because of estimation requirements for the dependent variable (described later), abnormal returns for 51 Facebook firms and 50 Twitter firms could not be estimated. Also, an additional 47 Facebook firms and 49 Twitter firms were eliminated due to contaminating events which might influence the firm's stock price (see the section below). Therefore, the final testable sample for Facebook contained 243 firms and the final sample for Twitter contained 303 firms (for a complete list of firms, see Appendix A).

\section{Confounding Events}

Firm adoption data was screened to ensure stock market reaction to a firm's adoption of a SNS was not an artifact of other confounding events (e.g., contaminating events, which could influence abnormal returns). For example, a firm might adopt a Twitter account on the same day as an earnings announcement, and therefore its abnormal return might be attributable to the firm's earnings report and not the adoption of Twitter. To control for potential contaminating factors, the final sample was cleaned. Consistent with prior research, contaminating events were defined as any announcement of restructuring, merger and acquisition, dividends, earnings announcements, earnings revisions, new product releases, new debt or equity issuance, executive team changes, or other material changes in operations (e.g., announcement of a new government contract) (Karniouchina et al., 2009). Confounding events were identified through analyzing press releases and SEC regulatory filings (DeFond et al., 2010). The window examined consisted of four days surrounding the event. This is based on suggestions from prior IS research suggesting the window to 
examine for confounding events should be larger to ensure these events are controlled for (Konchitchki \& O'Leary, 2011). Any firm with a confounding event in this window was removed which is consistent with prior event study research in information systems (Dobija et al., 2012; Teo et al., 2016).

\section{Independent and Control Variables}

Rogers (1995) describes five categories of technology adopters based on how quickly they decide to adopt that technology. He defines innovators as the first 2.5 percent of adopters of a technology within a population. Early adopters are the next 13.5 percent of adopters of a technology. The next 34 percent of the adopters are called the early majority. The 34 percent of adopters, which follow the early majority, are called the late majority, and the last 16 percent of technology adopters are considered laggards (Rogers, 1995). The focus of our research is on the first three categories: innovators, early adopters, and early majority. Innovators are defined as the first 2.5 percent of firms ( 21 firms) within our sampling frame to adopt the SNS; early adopters are the next 13.5 percent of firms (113 firms) within our sampling frame to adopt the SNS; and early majority are the remaining firms who have adopted the SNS, but were not within the first 16 percent of firms to adopt it. Firms who would normally be categorized as laggards or late majority are not included in the sample of firms.

Industry and firm specific control variables are included in the analysis (captured via Compustat). Firm level controls include size, return on assets, leverage, growth opportunity, and selling expenses, which are common control variables typically included in event studies (Boyd et al., 2010; Fama, 1998; Im et al., 2001). For instance, one might expect smaller firms to have larger stock price movement after adopting a SNS because SNS adoption might have more incremental value to the small firm relative to the large firm. Similarly, firms which are more profitable relative to their total assets (return on assets), as well as firms which have less debt (leverage) and are therefore less risky, might benefit more from SNS adoption due to their superior financial situation. A list of controls and their definition is included in Table 2.

\section{Dependent Variable: Abnormal Returns}

Following Campbell, Lo, and MacKinlay (1997), abnormal return is defined as the actual ex-post return of the stock over the event window minus the normal return of the firm over the event window. The normal return is the return that would be expected if the event did not take place. That is, the normal return would be the return that Firm $i$ expects at Time $t$ given that the firm did not adopt a SNS. As shown in Equation 1, abnormal returns are defined as:

$$
A R_{i t}=R_{i t}-E\left[R_{i t} \mid X_{t}\right]
$$

where $A R_{i t}, R_{i t}$, and $E\left[R_{i t}\right]$ are the abnormal, actual, and normal returns for Firm $i$ in Time $t$. $\mathrm{X}_{\mathrm{t}}$ is the conditioning information to determine normal performance in Time $t$. In order to predict normal performance in Equation 2, we utilize the traditional four-factor model that incorporates a firm's sensitivity to market returns, as well as a number of welldocumented market abnormalities related to market capitalization, book-to-market ratio (Fama \& French, 1996), and momentum (Carhart, 1997):

$$
E\left[R_{i t} \mid X_{t}\right]=\alpha_{i}+\beta_{i} R_{m t}+s_{i} S M B_{t}+h_{i} H M L_{t}+u_{i} U M D_{t}+\varepsilon_{i t}
$$

where

$R_{i t}$ is return of Stock $i$ at Time $t$,

$R_{m t}$ is return on the market in time (i.e. daily return on CRSP value-weighted index),

$\beta_{i}$ is a measure of Stock is sensitivity to market changes,

$\varepsilon_{i t}$ is the error term,

$S M B_{t}$ is the average return for the smallest stocks minus the average return for the largest stocks,

$H M L_{t}$ is the average return on stocks with highest book-to-market ratios minus the average return for the stocks with the lowest book-to-market ratios,

$U M D_{t}$ is the average return on high-performing portfolios minus the average return on low-return portfolios.

Combining Equations 1 and 2 give the standard equation for abnormal returns using the four-factor model to predict normal returns. Thus, abnormal returns are defined as the following (Equation 3):

$$
\begin{aligned}
& A R_{i t}=R_{i t}-\left(\hat{\alpha}_{i}+\hat{\beta}_{i} R_{m t}+\hat{s}_{i} S M B_{t}+\hat{h}_{i} H M L_{t}+\hat{u}_{i} U M D_{t}\right) \\
& \text { where } \hat{\alpha}_{i}, \hat{\beta}_{i}, \hat{s}_{i}, \hat{h}_{i}, \text { and } \hat{u}_{i} \text { are estimates of } \\
& \alpha_{i}, \beta_{i}, s_{i}, h_{i} \text {, and } u_{i} .
\end{aligned}
$$

These abnormal returns form the basis for the evaluation of stock market reaction to SNSs. Abnormal returns are accessed and extracted using Eventus $^{\circledR}$ software (via Wharton Research Data Services, WRDS). Table 2 summarizes the variables as well as their operationalization. 
Table 2. Variable Operationalization

\begin{tabular}{|c|c|}
\hline \multicolumn{2}{|l|}{ Dependent Variable } \\
\hline Abnormal Return (AR) & $\begin{array}{l}\text { Actual ex-post return of the stock over the event window minus the return that } \\
\text { would be expected if the event did not take place; Four-factor model: } A R_{i t}=R_{i t}- \\
\left(\alpha_{i}+\beta_{i} R_{m t}+\hat{s}_{i} S M B_{t}+\hat{h}_{i} H M L_{t}+u_{i} U M D_{t}+\varepsilon_{i t}\right) ; \text { see Campbell, Lo, and MacKinlay } \\
(1997) \text {, Fama and French (1996), and Carhart (1997) for more details. }\end{array}$ \\
\hline \multicolumn{2}{|l|}{ Independent Variables } \\
\hline Innovators (IN) & Innovators are defined as the first $2.5 \%$ of firms to adopt a technology. \\
\hline Early Adopters (EA) & Early adopters are the next $13.5 \%$ of firms to adopt a technology. \\
\hline Early Majority (EM) & The next $34 \%$ of the adopters are called the early majority. \\
\hline \multicolumn{2}{|l|}{ Control Variables } \\
\hline $\begin{array}{l}\text { Firm Size (S) } \\
\text { (Im et al., 2001) }\end{array}$ & Total assets of Firm $i$ in Adoption Year $t$ in millions. \\
\hline $\begin{array}{l}\text { Return on Assets (ROA) } \\
\text { (Krasnikov et al., 2009) }\end{array}$ & Net income divided by total assets of Firm $i$ in Year $t$. \\
\hline $\begin{array}{c}\text { Leverage (LEV) } \\
\text { (Dewan \& Ren, 2011) }\end{array}$ & Long-term debt divided by total assets of Firm $i$ in Year $t$. \\
\hline $\begin{array}{l}\text { Growth Opportunity (GROW) } \\
\text { (Fama, 1998) }\end{array}$ & $\begin{array}{l}\text { The ratio of the market value of equity to the book value of equity of Firm } i \text { in Year } \\
t \text {. }\end{array}$ \\
\hline $\begin{array}{l}\text { Selling Expenditures (SE) } \\
\text { (Morgan \& Rego, 2009) }\end{array}$ & Selling, general, and administrative expense (SG\&A) of Firm i in Year $t$ in millions. \\
\hline $\begin{array}{l}\text { Industry (IND) } \\
\text { (Bharadwaj et al., 1999) }\end{array}$ & Two digit SIC code \\
\hline
\end{tabular}

\section{Analysis}

Event studies center all events (i.e. SNS adoptions) at Day $t=0$. We used a 220-day estimation window (between Days 250 and 30) to estimate the normal or expected return. We use this broad event window to provide a direct comparison with other published studies using event study methodologies. Stopping the estimation 30 days prior to the event is necessary to avoid having any event-related information incorporated into the estimation of the normal return. The event window of interest for abnormal returns is the day that a firm adopts a SNS and the day afterward, or Day $t=0$ and $t=1$ (window: 0,1 ). If the stock market is closed on the day that the new adoption is announced, the subsequent open trading day was used. Using a $(0,1)$ window is consistent with prior research, which indicates that the majority price movement related to an event is incorporated immediately following the event (Karniouchina et al., 2009; Wright \& Ferris, 1997).

To evaluate the market's overall reaction to firms which adopt SNSs (Hypothesis 1), mean cumulative abnormal returns (MCAR) are analyzed. The cumulative abnormal return (CAR) is defined as the aggregated abnormal return over the two-day event window $(0,1)$, or Equation 4:

$$
C A R_{i}=\sum_{t=0}^{t=1} A R_{i t}
$$

Mean cumulative abnormal returns are then calculated by averaging the CAR for the entire sample of $\mathrm{N}$ firms (Equation 5):

$$
M C A R=\frac{1}{N} \sum_{i=1}^{N} C A R_{i}
$$

To determine statistical significance of the MCAR, the Portfolio Time-Series crude dependence adjustment (CDA) test will be analyzed. The Portfolio TimeSeries (CDA) is a way to handle cross sectional dependence. It estimates the abnormal return variance directly from the time series of observations of average abnormal returns during the estimation period (Brown \& Warner, 1980; Brown \& Warner, 1985). For robustness, significance will be required in both statistical tests. In general, positive (negative) abnormal returns during the $(0,1)$ window suggest that investors view the SNS as a profitable (unprofitable) decision that will increase (decrease) future cash flows of the firm. 
To evaluate how the rate of adoption affects firm-level abnormal returns (Hypotheses 2 and 3), our independent variables (rate of adoption) and controls (size, return on assets, leverage, growth potential, selling expenses, and industry) are regressed against our dependent variable (abnormal return). In particular, the following general linear model will be estimated for each Firm $i$ across both samples (Equation 6):

$A R_{i}=\gamma_{1}+\gamma_{2} I N_{i}+\gamma_{3} E A_{i}+\gamma_{4} S_{i}+\gamma_{5} R O A_{i}+\gamma_{6} L E V_{i}$ $+\gamma_{7} \mathrm{GROW}_{i}+\gamma_{8} \mathrm{SE}_{i}+\gamma_{9} I N D_{i}+v_{i}$

where $A R_{\mathrm{i}}$ is the abnormal return for Firm $i$ over the $(0,1)$ window; $I N_{i}$ is a dummy variable equal to 1 if Firm $i$ is in the first 2.5 percent of firms to adopt the SNS; $E A_{i}$ is a dummy variable equal to 1 if Firm $i$ is in the next 13.5 percent of firms to adopt the SNS; $S_{i}$ is a measure of the size of Firm $i ; \mathrm{ROA}_{i}$ is a measure of the firm's return on assets; $L E V_{i}$ is a measure of the firm's leverage; $\mathrm{GROW}_{\mathrm{i}}$ is a measure of the growth opportunities for Firm $i$; $S E_{i}$ is a measure of the selling expenses for Firm $i$; $I N D_{i}$ is an industry classification variable dividing the firms into 14 industries; and $\mathrm{v}_{\mathrm{i}}$ is the error term.

\section{Results}

To assess if the adoption of a new innovation leads to increased firm performance $\left(\mathrm{H}_{1}\right)$, MCARs are analyzed. In particular, $\mathrm{H}_{1}$ would be supported by a positive and significant MCAR. Separate MCARs are estimated for our two samples (one for Facebook and one for Twitter). Table 3 shows that on average firms significantly benefit from adopting SNSs. Firms which adopted Facebook saw a 1.20 percent $(p<0.001$ for CDA) abnormal jump in their stock price in the twoday window around the adoption; therefore, $\mathrm{H} 1 \mathrm{a}$ is supported. Firms that adopted Twitter experienced a 0.67 percent $(p<0.01$ for CDA) abnormal jump in their stock price during the same two-day window; therefore, $\mathrm{H} 1 \mathrm{~b}$ is supported.

Table 3. Overall Analysis of Abnormal Returns

\begin{tabular}{|lclrl|}
\hline Sample & $\begin{array}{l}\text { Sample } \\
\text { Size }\end{array}$ & $\begin{array}{l}\text { Event } \\
\text { Window }\end{array}$ & MCAR & $\begin{array}{l}\text { Portfolio } \\
\text { Time-Series } \\
\text { (CDA) }\end{array}$ \\
\hline Facebook & 243 & $(0,1)$ & $1.20 \%$ & $3.20^{* * *}$ \\
Twitter & 303 & $(0,1)$ & $0.67 \%$ & $2.05^{*}$ \\
\hline Note: $* * * p<0.001, * * p<0.01,{ }^{*} p<0.05$. \\
\hline
\end{tabular}

To examine the effect of the time of adoption on a firm's abnormal returns ( $\mathrm{H} 2$ and $\mathrm{H} 3$ ), a cross-sectional generalized least squares regression is analyzed. Equation 6 is estimated separately for the Facebook and Twitter samples. Table 4 shows the results from the regression models for Facebook and Twitter (note: the 12 control variables for industry were all found to be not significant and are not reported in the table).

Table 4. Cross-Sectional Generalized Least Squares Regression Models

\begin{tabular}{|c|c|c|}
\hline & \multicolumn{2}{|c|}{ Dependent Variables } \\
\hline & $\begin{array}{l}\text { Facebook } \\
\text { CAR }\end{array}$ & $\begin{array}{l}\text { Twitter } \\
\text { CAR }\end{array}$ \\
\hline \multicolumn{3}{|l|}{ Independent Variables } \\
\hline Intercept & $\begin{array}{l}0.20 \% \\
(1.38)\end{array}$ & $\begin{array}{l}0.39 \% \\
(0.19)\end{array}$ \\
\hline Innovators (IN) & $\begin{array}{l}0.80 \% \\
(0.47)\end{array}$ & $\begin{array}{l}-0.32 \% \\
(-0.26)\end{array}$ \\
\hline Early Adopters (EA) & $\begin{array}{l}2.12 \%{ }^{*} \\
(2.12)\end{array}$ & $\begin{array}{l}1.50 \% * \\
(2.42)\end{array}$ \\
\hline \multicolumn{3}{|l|}{ Control Variables } \\
\hline Firm Size (S) & $\begin{array}{r}0.26 \% \\
(-0.95)\end{array}$ & $\begin{array}{l}0.00 \% \\
(0.36)\end{array}$ \\
\hline Return on Assets (ROA) & $\begin{array}{l}-5.30 \% * * \\
(-2.57)\end{array}$ & $\begin{array}{l}-5.11 \% * \\
(-1.94)\end{array}$ \\
\hline Leverage (LEV) & $\begin{array}{l}-1.37 \% \\
(-0.90)\end{array}$ & $\begin{array}{l}-2.30 \% * \\
(-2.24)\end{array}$ \\
\hline Growth Opportunity (GROW) & $\begin{array}{l}0.00 \% \\
(0.14)\end{array}$ & $\begin{array}{r}0.00 \% \\
(-0.66)\end{array}$ \\
\hline Selling Expenditures (SE) & $\begin{array}{l}0.00 \% \\
(0.76)\end{array}$ & $\begin{array}{l}0.00 \% \\
(-0.34)\end{array}$ \\
\hline \multicolumn{3}{|c|}{$\begin{array}{l}\text { Industry (IND) - all industry dummy variables resulted in } p> \\
0.10\end{array}$} \\
\hline \multicolumn{3}{|c|}{$\begin{array}{l}\text { Note: } * * * p<0.001, * * p<0.01,{ }^{*} p<0.05 \text {. } \\
\text { t-values are in parentheses and have been adjusted for } \\
\text { heteroscedasticity based on White (1980). }\end{array}$} \\
\hline
\end{tabular}

For both samples, the innovator variable is not significant; therefore, $\mathrm{H} 2 \mathrm{a}$ and $\mathrm{H} 2 \mathrm{~b}$ are rejected. However, firms that were early adopters of Facebook had greater abnormal returns than later adopters (early majority) of the technology. On average, early adopters (i.e. fast followers) of Facebook had abnormal returns 2.12 percent $(p<0.05)$ higher than that of the early majority; therefore, $\mathrm{H} 3 \mathrm{a}$ is supported. Similarly, firms that were early adopters of Twitter had greater abnormal returns than the early majority. On average, early adopters of Twitter had abnormal returns 1.50 percent $(p<0.05)$ higher than that of the early majority; therefore, $\mathrm{H} 3 \mathrm{~b}$ is supported. To ensure robustness in our results, alternative estimation periods and benchmarks were calculated (see Appendix B). All alternative evaluations resulted in the similar results for all hypotheses. 


\section{Discussion}

Firms are continuously in pursuit of innovations. Public technologies such as social media enable competitors to easily copy any innovation. While adoption may result in value to the firm over time, it is unclear if (a) they provide an initial business value to the firm adopting them and (b) when is the time to adopt to leverage that initial business value. We analyzed firms' adoptions of two public SNSs-Facebook and Twitter. Our findings indicate that firms adopting these public technologies experienced a significant positive increase in firm value, but the increase was not uniform across firms. The time of adoption significantly influenced the value firms initially experienced. Interestingly, it was the fast followers (early adopters) who experienced a large gain in firm value, while the first movers (innovators) and later followers (early majority) did not. The size of this effect (2.1 percent and 1.5 percent) was meaningful as well as significant. Since we studied two separate and distinct public SNSs, it provides reassurance that the pattern and magnitude of the results are consistent (i.e. fast following firms adopting either Twitter or Facebook experienced similar increases in value).

Two potential reasons exist as why fast followers derived more value than first movers. First, the value of SNSs may lie not just in the technology but also in the size of its network of users (Kauffman et al., 2000; Schilling, 2002; Shapiro \& Varian, 1999). There appears to be an impact from network externalities enabling fast followers to leverage the impact of the technology. Thus, first movers may have moved too soon, when the technology had too few users to provide business value. By waiting until the technology had a larger network of users, fast followers were better able to capture business value.

A second possible explanation is that SNSs were developed for one purpose and adopted by firms for a different purpose. Technology changes faster than the social structures of use (DeSanctis \& Poole, 1994), so first movers moved too soon, before new social structures around the technology (i.e. a tool for firms to communicate with customers) were fully adopted by users. Fast followers entering later in the adoption lifecycle may have adopted at a time in which more individual users were changing their social structures to accommodate SNS use by firms. By waiting until the social structures of use were changing, fast followers were better able to capture business value.

\section{Implications for Research}

We believe that our findings have important implications for future research. First, we contribute to the existing research examining firm-level adoption of innovations by examining the impact of the adoption of public technologies on firm value. The timing of adoption of SNSs and other public technologies has not received much research attention in the organizational adoption of innovations because they are highly visible and easily copied. An individual firm has less control over public technologies as they are controlled by third parties and extensively used by the general public in a variety of instrumental ways that may not be germane to the way in which the firm wants to employ the technology. In this situation, our research shows that fast followers derive more business value from adoption than do first movers and the early majority of adopting firms. More research is needed to better understand the impact of timing on firm value during the adoption of other public technologies.

Second, SNSs are social technologies, which means that network effects may play a significant role in value. With these network externalities, the value of a technology to one user is affected by the number of other users (Kauffman et al., 2000; Schilling, 2002; Shapiro \& Varian, 1999). In the case of SNSs, the business value to firms is dependent on the value placed by other users of SNSs. That is, SNSs such as Facebook and Twitter are not valuable to their users (and hence firms) until the network of users has grown to a sufficient level. This provides one potential explanation as to why first movers do not gain business value.

Third, the nature of the industry being examined must be considered in the adoption process. SNSs provide opportunities that may not have the same utility for firms in all industries. By choosing to examine consumer-facing industries, we expand on innovation adoption by suggesting that researchers should focus on specific industries which are relevant to the innovation being adopted. Future research needs to examine whether a similar pattern of abnormal returns (i.e. business value) occurs for other, non-consumer facing industries. An interesting extension to this research would be to examine business value to firms for non-consumer facing social media technologies. For example, Linkedln is functionally similar in some ways to Facebook but has a different purpose; Linkedln is more professionally oriented than Facebook.

Finally, as previously mentioned, SNSs have social structures that change more slowly than the underlying technology. It takes some time for the social structures to evolve to the point where a critical mass of users embrace and accept the new social structures, so that firms can capture business value from the new forms of use. Further research is needed to understand how the social structures of SNS and other public Software as a Service (SaaS) technologies affect the business value that firms derive from adopting them. 


\section{Implications for Practice}

For firms, our findings suggest that fast followers derive greater initial business value than the firms that are the first to adopt a new social media. Thus, businesses moving first (i.e. first mover) may not derive an initial business value compared to fast followers. While this does not mean first movers will never derive business value, it suggests that firms may want to wait and let other firms innovate, and then follow them once the paths to success (and failure) have been uncovered by the first movers. When a new public social media technology appears, we advise firms to carefully monitor and adopt it once the user base is large enough and social structures support corporate use. One advantage of being a fast follower is that these firms often learn from the mistakes of the first movers and can develop better innovations for customers (Boeker, 1989).

It is unclear the extent to which this implication applies to other public technologies. We suggested that the two social media technologies we studied have network effects and slowly changing social structures around use (as they moved from individual to corporate use). Thus, we believe that this implication applies to other public technologies to the extent that they also have network effects and/or slowly changing social structures. So, a firm choosing to be a fast follower gains more benefits than an innovative first mover because the first mover acts before there is a large user base and before corporate use is widely, socially accepted. Thus, the challenge for firms is deciding when is the appropriate time to enter; that is, when will they be able to take advantage of being a fast follower before the technology enters the early adopter stages of diffusion.

Alternatively, if a firm misses the fast follower stage of adoption, then the question arises about adopting a social media technology or other public technology without knowing if it will provide clear business value for the firm. Consumer demand for company profiles in SNSs may induce firms to adopt this technology out of necessity to compete.

This is caused by consumer expectation set by early adopters that all companies should have an online SNS presence. Thus, once the adoption process enters later stages (after first movers and fast followers), the SNS adoption decision changes from one based on business value creation to one of necessity to remain competitive.

\section{Limitations}

As with any study, this research has limitations. First, our investigation focused only on consumer-oriented firms; results therefore may apply only to firms in these industries. Second, only publically traded U.S. firms were included in our sample, so results may not apply to privately held firms or non-U.S. firms. We limited our study to the earlier phases of the adoption process, which included innovators, early adopters, and early majority. Our focus is on abnormal returns from an initial competitive advantage which, based on prior research, occurs for those early in the adoption cycle with laggards not receiving similar benefits. Third, because we have classified firms into groups (innovators, early adopters, and early majority) based on when they adopted these two technologies, there are inherent time-based limitations. There is a strong correlation between each group and the year of adoption, and since the annual returns differ from year to year, the year of adoption may have influenced the results. Since we are focusing on a 1-3 day time window, we do not believe that the year had systematic effects on the results, but this remains a limitation. Finally, not all firms in our population have adopted Facebook or Twitter, so these technologies have not reached the mature stage of adoption needed to produce a late majority or laggard group of companies. This limits our findings to firms in the early phases of adoption (i.e. innovators, early adopters, and early majority).

\section{Conclusion}

Social media has become an important tool for firms attempting to reach customers. With the increasing number of social media technologies being introduced and the cost to develop a strategy for entering a new technology, firms must decide when the appropriate time to adopt a public social technology is. While this research does not examine the long-term benefits of first movers, we do find that there appears to be a second-mover advantage in social technology adoption.

\footnotetext{
Notes

${ }^{1}$ Number obtained from http://newsroom.fb.com/companyinfo/ as of $12 / 2015$

${ }^{2}$ From https://about.twitter.com/company as of 03/2016

${ }^{3}$ See salaries for social media positions on Indeed.com (Date Searched: 9/27/2015)

${ }^{4}$ The script can be obtained here: http://userscripts.org/scripts/show/87496

${ }^{5}$ For example, Home Depot's Twitter account was created on May 15, 2008. The website www.whendidyoujointwitter.com accesses Home Depot's API (http://twitter.com/users/show/homedepot.xml) and returns the 'created_at' field.
} 


\section{References}

Abrahamson, E. (1991). Managerial fads and fashions: The diffusion and rejection of innovations. The Academy of Management Review, 16(3), 586-612.

Abrahamson, E., \& Fairchild, G. (1999). Management fashion: Lifecycles, triggers, and collective learning processes. Administrative Science Quarterly, 44(4), 708-740.

Andoh-Baidoo, F. K., Osei-Bryson, K.-M., \& AmoakoGyampah, K. (2012). A hybrid decision tree based methodology for event studies and its application to e-commerce initiative announcements. SIGMIS Database, 44(1), 78-101.

Barney, J. B. (1991). Firm resources and sustained competitive advantage. Journal of Management, 17(1), 99-120.

Bharadwaj, A., Keil, M., \& Mähring, M. (2009). Effects of information technology failures on the market value of firms. The Journal of Strategic Information Systems, 18(2), 66-79.

Bharadwaj, A. S. (2000). A resource-based perspective on information technology capability and firm performance: An empirical investigation. MIS Quarterly, 24(1), 169-196.

Bharadwaj, A. S., Bharadwaj, S. G., \& Konsynski, B. R. (1999). Information technology effects on firm performance as measured by Tobin's $Q$. Management Science, 45(7), 1008-1024.

Boeker, W. 1989. Strategic change: The effects of founding and history. The Academy of Management Journal, 32(3), 489-515.

Boyd, D., \& Ellison, N. (2007). Social network sites: Definition, history, and scholarship. Journal of Computer-Mediated Communication, 13(1), 210230.

Boyd, E., Chandy, R., \& Cunha Jr, M. (2010). When do Chief Marketing Officers affect firm value? A customer power explanation. Journal of Marketing Research, 47(6), 1162-1176.

Brown, S. J., \& Warner, J. B. (1980). Measuring security price performance. Journal of Financial Economics, 8(3), 205-258.

Brown, S. J., \& Warner, J. B. (1985). Using daily stock returns: The case of event studies. Journal of Financial Economics, 14(1), 3-31.

Campbell, J. Y., Lo, A. W., \& MacKinlay, C. (1997). The econometrics of financial markets. Princeton, $\mathrm{NJ}$ : Princeton University Press.

Carhart, M. M. (1997). On persistence in mutual fund performance. The Journal of Finance, 52(1), 5782.

Carpenter, G. S., \& Nakamoto, K. (1989). Consumer preference formation and pioneering advantage. Journal of Marketing Research, 26(3), 285-298.
Choi, J. N., \& Chang, J. Y. (2009). Innovation implementation in the public sector: An integration of institutional and collective dynamics. Journal of Applied Psychology, 94(1), 245-253.

Choudhury, V., \& Karahanna, E. (2008). The relative advantage of electronic channels: A multidimensional view. MIS Quarterly, 32(1), 179200.

Crawford, M., \& Di Benedetto, A. (2008). New products management. Burr Ridge, IL: Irwin/McGraw-Hill.

Day, G., \& Fahey, L. (1988). Valuing market strategies. The Journal of Marketing, 52(3), 4557.

DeFond, M. L., Konchitchki, Y., McMullin, J. L., \& O'Leary, D. E. (2010). Does superior knowledge management increase shareholder value? American Accounting Association Annual Meeting, San Francisco.

Dehning, B., Richardson, V., \& Zmud, R. (2003). The value relevance of announcements of transformational information technology investments. MIS Quarterly, 27(4), 637-656.

DeSanctis, G., \& Poole, M. S. (1994). Capturing the complexity in advanced technology use: Adaptive structuration theory. Organization Science, 5(2), 121-147.

Dess, G. G., \& Picken, J. C. (2000). Changing roles: Leadership in the 21st century. Organizational Dynamics, 28(3), 18-34.

Dewan, S., \& Ren, F. (2007). Risk and return of information technology initiatives: Evidence from electronic commerce announcements. Information Systems Research, 18(4), 370-394.

Dewan, S., \& Ren, F. (2011). Information technology and firm boundaries: Impact on firm risk and return performance. Information Systems Research, 22(2), 369-388.

Dobija, D., Klimczak, K. M., Roztocki, N., \& Weistroffer, H. R. (2012). Information technology investment announcements and market value in transition economies: Evidence from Warsaw stock exchange. The Journal of Strategic Information Systems, 21(4), 308-319.

Dong, J. Q., \& Wu, W. (2015). Business value of social media technologies: Evidence from online user innovation communities. The Journal of Strategic Information Systems, 24(2), 113-127.

Doyle, P. (2000). Valuing marketing's contribution. European Management Journal, 18(3), 233-245.

Ellison, N. B., Steinfield, C., \& Lampe, C. (2007). The benefits of Facebook "friends": Social capital and college students' use of online social network sites. Journal of Computer-Mediated Communication, 12, 1143-1168. 
Evans, P. B., \& Wurster, T. S. (1997). Strategy and the new economics of information. Harvard Business Review, 75(5), 70-82.

Fama, E. F. (1970). Efficient capital markets: A review of theory and empirical work. The Journal of Finance, 25(2), 383-417.

Fama, E. F. (1998). Market efficiency, long-term returns, and behavioral finance. Journal of Financial Economics, 49(3), 283-306.

Fama, E. F., \& French, K. R. (1996). Multifactor explanations of asset pricing anomalies. The Journal of Finance, 51(1), 55-84.

Fichman, R. G. (2004). Going beyond the dominant paradigm for information technology innovation research: Emerging concepts and methods. Journal of the Association for Information Systems, 5(8), 314-355.

Fichman, R. G., \& Kemerer, C. F. (1999). The illusory diffusion of innovation: An examination of assimilation gaps. Information Systems Research, 10(3), 255-275.

Fiol, C. M., \& O'Connor, E. J. (2003). Waking up! Mindfulness in the face of bandwagons. The Academy of Management Review, 28(1), 54-70.

Gnyawali, D. R., Weiguo, F., \& Penner, J. (2010). Competitive actions and dynamics in the digital age: An empirical investigation of social networking firms. Information Systems Research, 21(3), 594-613.

Goode, S. (2005). Something for nothing: Management rejection of open source software in Australia's top firms. Information Technology \& Management, 42(5), 669-681.

Goode, S., \& Stevens, K. (2000). An analysis of the business characteristics of adopters and nonadopters of world wide web technology. Information Technology and Management, 1(1), 129-154.

Guan, L., Sutton, S. G., Chang, C. J., \& Arnold, V. (2006). Further evidence on shareholder wealth effects of announcements for newly created $\mathrm{ClO}$ positions. SIGMIS Database, 37(2-3), 176-191.

Hale, D. (2010). Social networking: The new marketing channel. Journal of Business Management and Entrepreneurship, 1(9), 1-15.

Hansen, R., \& Kein, S. S. (2015). Hummel's digital transformation toward omnichannel retailing: Key lessons learned. MIS Quarterly Executive, 14(2), 51-66.

Hidding, G. J., \& Williams, J. R. (2003). Are there first-mover advantages in B2B ecommerce technologies? Proceedings of the 36th Annual Hawaii International Conference on Information Systems.

Holzner, S. (2009). Facebook marketing: Leverage social media to grow your business. Que Publishing.
Hoppe, H. (2000). Second-mover advantages in the strategic adoption of new technology under uncertainty. International Journal of Industrial Organization, 18(2), 315-338.

Im, K. S., Dow, K. E., \& Grover, V. (2001). Research Report: A Reexamination of It Investment and the Market Value of the Firm--an Event Study Methodology. Information Systems Research, 12(1), 103.

Irani, Z., Ghoneim, A., \& Love, P. (2006). Evaluating cost taxonomies for information systems management. European Journal of Operational Research, 173(3), 1103-1122.

Jeyaraj, A., Rottman, J. W., \& Lacity, M. C. (2006). A review of the predictors, linkages, and biases in IT innovation adoption research. Journal of Information Technology, 21(1), 1-1-23.

Jones, C. and USA Today (2009). Jetblue and United give Twitter a try to sell airline seats fast. $A B C$ News. Retrieved from http://abcnews.go.com/Travel/story?id=8235518\& page $=1$

Kalyanaram, G., Robinson, W. T., \& Urban, G. L. (1995). Order of market entry: Established empirical generalizations, emerging empirical generalizations, and future research. Marketing Science, 14(3), G212.

Karniouchina, E. V., Moore, W. L., \& Cooney, K. J. (2009). Impact of mad money stock recommendations: Merging financial and marketing perspectives. The Journal of Marketing, 73(6), 244-266.

Kauffman, R. J., McAndrews, J., \& Yu-Ming, W. (2000). Opening the "black box" of network externalities in network adoption. Information Systems Research, 11(1), 61-82.

Keller, K. L. (1993). Conceptualizing, measuring, and managing customer-based brand equity. The Journal of Marketing, 57(1), 1-22.

Kerin, R. A., Varadarajan, P. R., \& Peterson, R. A. (1992). First-mover advantage: A synthesis, conceptual framework, and research propositions. The Journal of Marketing, 56(4), 3352.

Kettinger, W., Grover, V., Guha, S., \& Segars, A. (1994). Strategic information systems revisited: A study in sustainability and performance. MIS Quarterly, 18(1), 31-58.

Konchitchki, Y., \& O'Leary, D. E. (2011). Event study methodologies in information systems research. International Journal of Accounting Information Systems, 12(2), 99-115.

Krasnikov, A., Mishra, S., \& Orozco, D. (2009). Evaluating the financial impact of branding using trademarks: A framework and empirical evidence. Journal of Marketing, 73(6), 154-166. 
Lee, H., Smith, K. G., Grimm, C. M., \& Schomburg, A. (2000). Timing, order and durability of new product advantages with imitation. Strategic Management Journal, 21(1), 23-30.

Liang, T. P., Czaplewski, A. J., Klein, G., \& Jiang, J. J. (2009). Leveraging first-mover advantages in Internet-based consumer services. Communications of the ACM, 52(6), 146-148.

Lieberman, M. B., \& Montgomery, D. B. (1988). Firstmover advantages. Strategic Management Journal, 9(1), 41-58.

Lieberman, M. B., \& Montgomery, D. B. (1998). Firstmover (dis)advantages: Retrospective and link with the resource-based view. Strategic Management Journal, 19(12), 1111-1125.

Lyytinen, K., \& Newman, M. (2008). Explaining information systems change: A punctuated sociotechnical change model. European Journal of Information Systems, 17, 589-613.

McAfee, A., \& Brynjolfsson, E. (2008). Investing in the it that makes a competitive difference. Harvard Business Review, 89(7/8), 98-107.

Mellahi, K., \& Johnson, M. (2000). Does it pay to be a first mover in ecommerce? The case of Amazon.com. Management Decision, 38(7), 445452.

Melville, N., Kraemer, K., \& Gurbaxani, V. (2004). Review: Information technology and organizational performance: An integrative model of IT business value. MIS Quarterly, 28(2), 283322.

Merali, Y., Papadopoulos, T., \& Nadkarni, T. (2012). Information systems strategy: Past, present, future? The Journal of Strategic Information Systems, 21(2), 125-153.

Mohr, S. (2012). What is worth the money when it comes to social media? Retrieved July 12, 2012, from http://socialmediatoday.com/sarahmohr/472739/what-worth-money-when-it-comessocial-media

Morgan, N. A., \& Rego, L. L. (2009). Brand portfolio strategy and firm performance. Journal of Marketing, 73(1), 59-74.

My Starbucks Idea (2009). Happy birthday MSI! Retrieved May 9, 2011. Available at http://blogs.starbucks.com/blogs/customer/archiv e/(2009)/03/19/happy-birthday-msi.aspx

Oh, W., \& Pinsonneault, A. (2007). On the assessment of the strategic value of information technologies: Conceptual and analytical approaches. MIS Quarterly, 31(2), 239-265.

Orlikowski, W. J., \& Lacono, C. S. (2001). Research commentary: Desperately seeking the 'it' in IT research-A call to theorizing the IT artifact. Information Systems Research, 12(2), 121-134.
Peteraf, M. (1993). The cornerstones of competitive advantage: A resource-based view. Strategic Management Journal, 14(3), 179-191.

Poletti, M. J., Engelland, B. T., \& Ling, H. G. (2011). An empirical study of declining lead times: Potential ramifications on the performance of early market entrants. Journal of Marketing Theory \& Practice, 19(1), 27-38.

Ranganathan, C., \& Brown, C. V. (2006). ERP investments and the market value of firms: Toward an understanding of influential ERP project variables. Information Systems Research, 17(2), 145-161.

Rogers, E. (1995). Diffusion of innovations (4th ed.). New York: Free Press.

Rosen, P. A., \& Phillips, M. H. (2011). Marketing and the rise of web 2.0: Expanding opportunity, increasing challenge. Review of Business Information Systems, 15(3), 35-42.

Rosenkopf, L., \& Abrahamson, E. (1999). Modeling reputational and informational influences in threshold models of bandwagon innovation diffusion. Computational \& Mathematical Organization Theory, 5(4), 361-384.

Roztocki, N., \& Weistroffer, H. R. (2006). Stock price reaction to investments in information technology: The relevance of cost management systems. Electronic Journal of Information Systems Evaluation, 9(1).

Roztocki, N., \& Weistroffer, H. R. (2009). Event studies in information systems research: An updated review. Fifteenth Americas Conference on Information Systems, San Francisco, CA, 6-9.

Santhanam, R., \& Hartono, E. (2003). Issues in linking information technology capability to firm performance. MIS Quarterly, 27(1), 125-153.

Schilling, M. A. (2002). Technology success and failure in winner-take-all markets: The impact of learning orientation, timing, and network externalities. The Academy of Management Journal, 45(2), 387-398.

Schoemaker, P. J. H. (1990). Strategy, complexity and economic rent. Management Science, 36(10), 1178-1192.

Shankar, V., \& Carpenter, G. S. (2012). Late-mover strategies. In V. Shankar \& G.S. Carpenter (Eds.), Handbook of marketing strategy, Northhampton, Massachusetts: Edward Elgar Publishing.

Shankar, V., Carpenter, G. S., \& Krishnamurthi, L. (1998). Late mover advantage: How innovative late entrants outsell pioneers. Journal of Marketing Research, 35(1), 54-70.

Shapiro, C., \& Varian, H. (1999). Information rules A strategic guide the network economy. Boston, MA: Harvard Business School Press. 
Shih, C. (2014). What's the endgame for social media? Harvard Business Review.

Srivastava, R. K., Fahey, L., \& Christensen, H. K. (2001). The resource-based view and marketing: The role of market-based assets in gaining competitive advantage. Journal of Management, 27(6), 777-802.

Srivastava, R. K., Shervani, T. A., \& Fahey, L. (1998). Market-based assets and shareholder value: $A$ framework for analysis. The Journal of Marketing, 62(1), 2-18.

Suarez, F. F., \& Lanzolla, G. (2007). The role of environmental dynamics in building a first mover advantage theory. Academy of Management Review, 32(2), 377-392.

Subramani, M., \& Walden, E. (2001). The impact of e-commerce announcements on the market value of firms. Information Systems Research, 12(2), 135.

Swanson, E. B., \& Ramiller, N. C. (2004). Innovating mindfully with information technology. MIS Quarterly, 28(4), 553-583.

Sweeney, P. (2012). Social media costs and best practices. Retrieved from http://socialmediatoday.com/pjsweeney/503818/s ocial-media-costs-and-best-practices

Teo, T. S. H., Nishant, R., \& Koh, P. B. L. (2016). Do shareholders favor business analytics announcements? The Journal of Strategic Information Systems, 25(4), 259-276.

Trusov, M., Bucklin, R. E., \& Pauwels, K. (2009). Effects of word-of-mouth versus traditional marketing: Findings from an internet social networking site. Journal of Marketing, 73(5), 90102.

Tushman, M. L., \& O'Reilly, C. A., III. (1996). Ambidextrous organizations: Managing evolutionary and revolutionary change. California Management Review, 38(4), 8-30.

VanderWerf, P. A., \& Mahon, J. F. (1997). Metaanalysis of the impact of research methods on findings of first-mover advantage. Management Science, 43(11), 1510-1519.

Wade, M., \& Hulland, J. (2004). The resource-based view and information systems research: Review, extension, and suggestions for future research. MIS Quarterly, 28(1), 107-142.

Weber, L. (2009). Marketing to the social web: How digital customer communities build your business. Hoboken, NJ: John Wiley \& Sons.

Wejnert, B. (2002). Integrating models of diffusion of innovations: A conceptual framework. Annual Review of Sociology, 28(1), 297-326.
White, H. (1980). A heteroskedasticity-consistent covariance matrix estimator and a direct test for heteroskedasticity. Econometrica, 48(4), 817838.

Wright, P., \& Ferris, S. P. (1997). Agency conflict and corporate strategy: The effect of divestment on corporate value. Strategic Management Journal, 18(1), 77-83.

Xia, Y., \& Zhang, G. P. (2010). The impact of the online channel on retailers' performances: An empirical evaluation. Decision Sciences, 41(3), 517-546.

\section{About the Authors}

Jeff Cummings is an Associate Professor of Information Systems in the Cameron School of Business at University of North Carolina Wilmington. He received his Ph.D. from Indiana University. His research interests include the impacts of social media on the organization, healthcare IT, and privacy/security. His work has been published or is forthcoming in Management Information Systems Quarterly, Journal of Management Information Systems, IEEE Security \& Privacy, and Journal of the American Society for Information Science.

Alan R. Dennis is Professor of Information Systems and holds the John T. Chambers Chair of Internet Systems in the Kelley School of Business at Indiana University. He was named a Fellow of the Association for Information Systems in 2012. Professor Dennis has written more than 150 research papers, and has won numerous awards for his theoretical and applied research. His research focuses on three main themes: team collaboration, IT for the subconscious, and information security. He is co-Editor-in-Chief of AIS Transactions on Replication Research and Vice President for Conferences for the Association for Information Systems. He also has written four books (two on data communications and networking, and two on systems analysis and design).

Shawn M. O'Donoghue is a Research Associate at the University of Memphis. He graduated from the Kelley School of Business at Indiana University with a Ph.D. in finance. His research interests are in empirical asset pricing and empirical and theoretical market microstructure.

Kevin Cooney is currently a Lead Data Scientist at Amazon, Inc. Prior to Amazon, he worked for TripAdvisor, eBay, and was a Ph.D. candidate at Indiana University conducting research on marketing strategy. His work has been published in Journal of Marketing. 


\section{Appendix A}

Table A 1. Event Study Firms: Facebook

\begin{tabular}{|c|c|c|c|}
\hline Permno & Firm & Permno & Firm \\
\hline 10147 & E M C CORP MA & 47466 & NEW YORK TIMES CO A \\
\hline 11038 & NETWORK EQUIPMENT TECHNOLOGIES & 47677 & CINCINNATI BELL INC NEW \\
\hline 11267 & CATO CORP NEW A & 47941 & GANNETT INC \\
\hline 11308 & COCA COLA CO & 49154 & TARGET CORP \\
\hline 11510 & BENIHANA INC A & 49429 & DILLARDS INC A \\
\hline 11891 & M G M MIRAGE & 51692 & PIER 1 IMPORTS INC DE \\
\hline 12173 & GENERAL COMMUNICATION INC A & 52090 & MCCORMICK \& CO INC \\
\hline 12188 & HEARUSA INC & 53225 & WASHINGTON POST CO B \\
\hline 14461 & SONESTA INTERNATIONAL HOTELS CP & 53866 & FAMILY DOLLAR STORES INC \\
\hline 14541 & CHEVRON CORP NEW & 55213 & RUBY TUESDAY INC \\
\hline 14593 & APPLE INC & 55976 & WAL MART STORES INC \\
\hline 14816 & TOOTSIE ROLL INDS INC & 57330 & FRISCHS RESTAURANTS INC \\
\hline 15560 & RADIOSHACK CORP & 58683 & SOUTHWEST AIRLINES CO \\
\hline 16600 & HERSHEY CO & 59555 & HONDA MOTOR LTD \\
\hline 16678 & KROGER COMPANY & 60628 & FEDEX CORP \\
\hline 17005 & C V S CAREMARK CORP & 63781 & UNIT CORP \\
\hline 17961 & BRIGGS \& STRATTON CORP & 64020 & LUBYS INC \\
\hline 18403 & PENNEY J C CO INC & 65429 & SYMS CORP \\
\hline 18570 & BOB EVANS FARMS INC & 65752 & TEAM INC \\
\hline 19828 & WENDYS ARBYS GROUP INC & 65875 & VERIZON COMMUNICATIONS INC \\
\hline 24459 & PITNEY BOWES INC & 66093 & A T \& T INC \\
\hline 27633 & RYDER SYSTEMS INC & 66181 & HOME DEPOT INC \\
\hline 27828 & HEWLETT PACKARD CO & 66384 & WESTERN DIGITAL CORP \\
\hline 27983 & XEROX CORP & 70033 & HARLEY DAVIDSON INC \\
\hline 28804 & ALASKA AIRGROUP INC & 70500 & COCA COLA ENTERPRISES INC \\
\hline 29890 & B P PLC & 75100 & TIFFANY \& CO NEW \\
\hline 30737 & DRESS BARN INC & 75104 & C B S CORP NEW A \\
\hline 32540 & EMULEX CORP & 75261 & MCCLATCHY CO A \\
\hline 32803 & HOLLY CORP & 75320 & UNITED STATES CELLULAR CORP \\
\hline 36468 & SHERWIN WILLIAMS CO & 75432 & C E C ENTERTAINMENT INC \\
\hline 39087 & SPRINT NEXTEL CORP & 75489 & STAPLES INC \\
\hline 39731 & GRAY TELEVISION INC A & 75573 & OFFICE DEPOT INC \\
\hline 40440 & DIEBOLD INC & 75632 & REPSOL YPF S A \\
\hline 42059 & WEIS MARKETS INC & 76217 & WET SEAL INC A \\
\hline 43449 & MCDONALDS CORP & 76282 & AUTONATION INC DEL \\
\hline 45560 & INTERPHASE CORP & 76360 & GOOD TIMES RESTAURANTS INC \\
\hline 46923 & PRIMEENERGY CORP & 76568 & SONIC CORP \\
\hline
\end{tabular}




\begin{tabular}{|c|c|c|c|}
\hline \multicolumn{4}{|c|}{ Table A 1 (Continued). Event Study Firms: Facebook } \\
\hline Permno & Firm & Permno & Firm \\
\hline 76592 & DIAGEO PLC & 80971 & DUCKWALL ALCO STORES INC NEW \\
\hline 76605 & AUTOZONE INC & 81010 & STRATASYS INC \\
\hline 76655 & TOYOTA MOTOR CORP & 81133 & TELECOM ARGENTINA S A B \\
\hline 76671 & ANNTAYLOR STORES CORP & 81294 & WD $40 \mathrm{CO}$ \\
\hline 76695 & PANERA BREAD CO A & 81481 & DOLLAR TREE INC \\
\hline 76708 & DEVRY INC DEL & 81654 & BORDERS GROUP INC \\
\hline 76750 & MONRO MUFFLER BRAKE INC & 81669 & PORTUGAL TELECOM S G P S SA \\
\hline 76795 & ZEBRA TECHNOLOGIES CORP A & 82287 & CRAY INC \\
\hline 77186 & PERFUMANIA HOLDINGS INC & 82643 & LEXMARK INTERNATIONAL INC NEW A \\
\hline 77281 & WHOLE FOODS MARKET INC & 82720 & LEARNING TREE INTERNATIONAL INC \\
\hline 77453 & JACK IN THE BOX INC & 82830 & NICE SYSTEMS LTD \\
\hline 77516 & MENS WEARHOUSE INC & 83011 & WILLIAMS SONOMA INC \\
\hline 77530 & STEIN MART INC & 83604 & S K TELECOM CO LTD \\
\hline 77606 & KOHLS CORP & 83939 & HOT TOPIC INC \\
\hline 77610 & UNIVERSAL DISPLAY CORP & 83976 & ABERCROMBIE \& FITCH CO A \\
\hline 77669 & FINISH LINE INC A & 84042 & PENSKE AUTOMOTIVE GROUP INC \\
\hline 77702 & STARBUCKS CORP & 84203 & FAMOUS DAVES OF AMERICA \\
\hline 77902 & CHEESECAKE FACTORY INC & 84319 & LITHIA MOTORS INC \\
\hline 77928 & COMPANIA CERVECERIAS UNIDAS S A & 84416 & COLDWATER CREEK INC \\
\hline 78050 & BOOKS A MILLION INC & 84555 & OVERLAND STORAGE INC \\
\hline 78082 & SPORT CHALET INC B & 84576 & CHINA EASTERN AIRLINES CORP LTD \\
\hline 78877 & CHESAPEAKE ENERGY CORP & 84621 & LOGITECH INTERNATIONAL SA \\
\hline 78900 & NATHANS FAMOUS INC NEW & 85032 & QWEST COMMUNICATIONS INTL INC \\
\hline 78999 & PACIFIC SUNWEAR OF CA INC & 85173 & COINSTAR INC \\
\hline 79007 & SHOE CARNIVAL INC IN & 85232 & B J S WHOLESALE CLUB INC \\
\hline 79103 & O REILLY AUTOMOTIVE INC & 85333 & DOT HILL SYSTEMS CORP \\
\hline 79299 & PAPA JOHNS INTL INC & 85348 & YUM BRANDS INC \\
\hline 79411 & PETSMART INC & 85390 & CHILDRENS PLACE RTL STORES INC \\
\hline 79618 & PIZZA INN INC NEW & 85421 & CHINA MOBILE LTD \\
\hline 79667 & BARNES \& NOBLE INC & 85445 & INTERMEC INC \\
\hline 79672 & ZALE CORP NEW & 85452 & AC MOORE ARTS AND CRAFTS INC \\
\hline 79884 & WEST MARINE INC & 85502 & IDENTIVE GROUP INC \\
\hline 80286 & TRACTOR SUPPLY CO NEW & 85616 & LAN AIRLINES S A \\
\hline 80432 & AMERICAN EAGLE OUTFITTERS INC N & 85886 & PC CONNECTION INC \\
\hline 80544 & JOS A BANK CLOTHIERS INC & 85939 & RED LION HOTELS CORP \\
\hline 80638 & MULTIBAND CORP & 86209 & HASTINGS ENTERTAINMENT INC \\
\hline 80682 & FERRELLGAS PARTNERS L P & 86715 & CORINTHIAN COLLEGES INC \\
\hline 80857 & VILLAGE SUPER MARKET INC A & 86822 & EXTREME NETWORKS INC \\
\hline 80924 & SIRIUS X M RADIO INC & 86866 & TUESDAY MORNING CORP \\
\hline 80955 & WILLAMETTE VALLEY VINYDS INC & 86924 & THESTREET COM \\
\hline
\end{tabular}




\begin{tabular}{|c|c|c|c|}
\hline \multicolumn{4}{|c|}{ Table A 1 (Continued). Event Study Firms: Facebook } \\
\hline Permno & Firm & Permno & Firm \\
\hline 87043 & QUANTUM CORP & 90209 & JACKSON HEWITT TAX SERVICE INC \\
\hline 87055 & COSTCO WHOLESALE CORP NEW & 90248 & DOMINOS PIZZA INC \\
\hline 87105 & DRUGSTORE COM INC & 90286 & MCCORMICK \& SCHMICKS SEAFOOD RE \\
\hline 87251 & RADWARE LTD & 90371 & BUILD A BEAR WORKSHOP INC \\
\hline 87339 & PARTNER COMMUNICATIONS CO LTD & 90387 & NEW YORK \& CO INC \\
\hline 87538 & IPARTY CORP & 90427 & TEXAS ROADHOUSE INC A \\
\hline 88167 & HEALTHSTREAM INC & 90491 & GREAT WOLF RESORTS INC \\
\hline 88172 & KRISPY KREME DOUGHNUTS INC & 90657 & VERIFONE HOLDINGS INC \\
\hline 88490 & PETROLEO BRASILEIRO SA PETROBRA & 90720 & BUILDERS FIRSTSOURCE INC \\
\hline 88494 & TATA COMMUNICATIONS LTD & 90735 & LINCOLN EDUCATIONAL SVCS CORP \\
\hline 88510 & CALIFORNIA PIZZA KITCHEN INC & 90808 & EXPEDIA INC DE \\
\hline 88646 & STE C INC & 90825 & A C C O BRANDS CORP \\
\hline 88658 & TELUS CORP & 90865 & KONA GRILL INC \\
\hline 88742 & SHENANDOAH TELECOM COMPANY & 90896 & CARIBOU COFFEE CO INC \\
\hline 88779 & ICAD INC & 90969 & DOVER SADDLERY INC \\
\hline 89030 & PRINCETON REVIEW INC & 90972 & JONES SODA CO \\
\hline 89102 & GRANITE CITY FOOD \& BREWERY LTD & 90983 & PEOPLES BANCORP NC INC NEW \\
\hline 89217 & ADVANCE AUTO PARTS INC & 91014 & DELIA S INC NEW \\
\hline 89301 & GAMESTOP CORP NEW A & 91068 & CHIPOTLE MEXICAN GRILL INC A \\
\hline 89353 & JETBLUE AIRWAYS CORP & 91096 & MORGANS HOTEL GROUP CO \\
\hline 89394 & OVERSTOCK COM INC DEL & 91099 & NTELOS HOLDINGS CORP \\
\hline 89399 & AEROPOSTALE INC & 91117 & MORTONS RESTAURANT GROUP INC NE \\
\hline 89413 & BIG 5 SPORTING GOODS CORP & 91237 & VONAGE HOLDINGS CORP \\
\hline 89449 & KIRKLANDS INC & 91302 & J CREW GROUP INC \\
\hline 89453 & RED ROBIN GOURMET BURGERS INC & 91354 & GOLFSMITH INTL HLDGS INC \\
\hline 89540 & DICKS SPORTING GOODS INC & 91376 & ATLAS PIPELINE HOLDINGS L P \\
\hline 89581 & CHINA TELECOM CORP LTD & 91391 & WINDSTREAM CORP \\
\hline 89617 & EQUINIX INC & 91392 & WYNDHAM WORLDWIDE CORP \\
\hline 89641 & SEAGATE TECHNOLOGY & 91416 & HANESBRANDS INC \\
\hline 89644 & VIRGIN MEDIA INC & 91507 & SUSSER HOLDINGS CORP \\
\hline 89761 & CYCLE COUNTRY ACCESSORIES CORP & 91556 & ROSS STORES INC \\
\hline 89896 & JO ANN STORES INC & 91575 & HERTZ GLOBAL HOLDINGS INC \\
\hline 89904 & BUFFALO WILD WINGS INC & 91624 & WINN DIXIE STORES INC \\
\hline 89919 & PINNACLE AIRLINES CORP & 91659 & ALLEGIANT TRAVEL CO \\
\hline 89932 & KNOLOGY INC & 91683 & SALLY BEAUTY HOLDINGS INC \\
\hline 89973 & UNIVERSAL TECHNICAL INSTITUTE I & 91727 & TRAVELCENTERS AMERICA LLC \\
\hline 90009 & GLOBAL CROSSING LTD & 91729 & ZION OIL \& GAS INC \\
\hline 90012 & PETMED EXPRESS INC & 91888 & ARUBA NETWORKS INC \\
\hline 90187 & BLUE NILE INC & 91926 & DELTA AIR LINES INC \\
\hline 90194 & STANDARD PARKING CORP & 91937 & METROPCS COMMUNICATIONS INC \\
\hline
\end{tabular}




\begin{tabular}{|c|l|c|c|l|}
\hline \multicolumn{5}{|c|}{ Table A 1 (Continued). Event Study Firms: Facebook } \\
\hline Permno & Firm & Permno & Firm \\
\hline 91973 & ACORN INTERNATIONAL INC & 92400 & LUMBER LIQUIDATORS INC \\
\hline 92177 & HHGREGG INC & 92449 & REEDS INC \\
\hline 92211 & VOLTAIRE LTD & 92793 & ECOPETROL S A \\
\hline 92293 & TERADATA CORP DE & 92902 & BRIDGEPOINT EDUCATION INC \\
\hline 92322 & ULTA SALON COSMETICS \& FRAG INC & & & \\
\hline
\end{tabular}

Table A 2. Event Study Firms: Twitter

\begin{tabular}{|c|c|c|c|}
\hline Permno & Firm & Permno & Firm \\
\hline 10259 & SIGMA DESIGNS INC & 33099 & IMPERIAL OIL LTD \\
\hline 11038 & NETWORK EQUIPMENT TECHNOLOGIES & 35238 & PEP BOYS MANNY MOE \& JACK \\
\hline 11081 & DELL INC & 36468 & SHERWIN WILLIAMS CO \\
\hline 11308 & COCA COLA CO & 39490 & APACHE CORP \\
\hline 11379 & CASUAL MALE RETAIL GROUP INC & 40440 & DIEBOLD INC \\
\hline 11382 & SAKS INC & 40539 & T J X COMPANIES INC NEW \\
\hline 11478 & BERRY PETROLEUM CO A & 42059 & WEIS MARKETS INC \\
\hline 11618 & FASTENAL COMPANY & 43449 & MCDONALDS CORP \\
\hline 11762 & EATON CORP & 46922 & RITE AID CORP \\
\hline 11850 & EXXON MOBIL CORP & 47677 & CINCINNATI BELL INC NEW \\
\hline 11891 & M G M MIRAGE & 47706 & FEDERAL SIGNAL CORP \\
\hline 12188 & HEARUSA INC & 49154 & TARGET CORP \\
\hline 12490 & INTERNATIONAL BUSINESS MACHS CO & 49429 & DILLARDS INC A \\
\hline 14541 & CHEVRON CORP NEW & 51692 & PIER 1 IMPORTS INC DE \\
\hline 14656 & SUNOCO INC & 53866 & FAMILY DOLLAR STORES INC \\
\hline 15560 & RADIOSHACK CORP & 55976 & WAL MART STORES INC \\
\hline 16678 & KROGER COMPANY & 57817 & NORDSTROM INC \\
\hline 17005 & C V S CAREMARK CORP & 58683 & SOUTHWEST AIRLINES CO \\
\hline 17671 & BENIHANA INC & 59010 & GAP INC \\
\hline 18570 & BOB EVANS FARMS INC & 59089 & BRISTOW GROUP INC \\
\hline 19502 & WALGREEN CO & 59555 & HONDA MOTOR LTD \\
\hline 21742 & CASEYS GENERAL STORES INC & 60599 & CENTURYTEL INC \\
\hline 22753 & CHARMING SHOPPES INC & 60628 & FEDEX CORP \\
\hline 23887 & FRONTIER COMMUNICATIONS CORP & 61399 & LOWES COMPANIES INC \\
\hline 24459 & PITNEY BOWES INC & 63773 & TELEPHONE \& DATA SYSTEMS INC \\
\hline 27562 & CRACKER BARREL OLD COUNTRY STOR & 64020 & LUBYS INC \\
\hline 27828 & HEWLETT PACKARD CO & 65429 & SYMS CORP \\
\hline 27983 & XEROX CORP & 65752 & TEAM INC \\
\hline 28804 & ALASKA AIRGROUP INC & 66093 & $\mathrm{~A} T \& \mathrm{~T} I N C$ \\
\hline 29890 & B P PLC & 66181 & HOME DEPOT INC \\
\hline 30737 & DRESS BARN INC & 66384 & WESTERN DIGITAL CORP \\
\hline 32540 & EMULEX CORP & 66739 & SWIFT ENERGY CO \\
\hline
\end{tabular}




\begin{tabular}{|c|c|c|c|}
\hline \multicolumn{4}{|c|}{ Table A 2 (Continued). Event Study Firms: Twitter } \\
\hline Permno & Firm & Permno & Firm \\
\hline 66835 & B T GROUP PLC & 78045 & MAGNA INTERNATIONAL INC A \\
\hline 67467 & BIG LOTS INC & 78050 & BOOKS A MILLION INC \\
\hline 68866 & SASOL LTD & 78082 & SPORT CHALET INC B \\
\hline 70033 & HARLEY DAVIDSON INC & 78841 & VAALCO ENERGY INC \\
\hline 70332 & ANADARKO PETROLEUM CORP & 78877 & CHESAPEAKE ENERGY CORP \\
\hline 75100 & TIFFANY \& CO NEW & 78999 & PACIFIC SUNWEAR OF CA INC \\
\hline 75104 & C B S CORP NEW A & 79007 & SHOE CARNIVAL INC IN \\
\hline 75142 & TELEFONOS DE MEXICO S A B DE C A & 79103 & O REILLY AUTOMOTIVE INC \\
\hline 75261 & MCCLATCHY CO A & 79299 & PAPA JOHNS INTL INC \\
\hline 75316 & SOTHEBYS & 79411 & PETSMART INC \\
\hline 75418 & VODAFONE GROUP PLC NEW & 79618 & PIZZA INN INC NEW \\
\hline 75432 & C E C ENTERTAINMENT INC & 79667 & BARNES \& NOBLE INC \\
\hline 75489 & STAPLES INC & 79839 & ITRON INC \\
\hline 75573 & OFFICE DEPOT INC & 79881 & URBAN OUTFITTERS INC \\
\hline 75632 & REPSOL YPF S A & 79884 & WEST MARINE INC \\
\hline 75831 & DIGI INTERNATIONAL INC & 80070 & SUNCOR ENERGY INC \\
\hline 76149 & SAFEWAY INC & 80089 & GRUPO TELEVISA SA \\
\hline 76282 & AUTONATION INC DEL & 80286 & TRACTOR SUPPLY CO NEW \\
\hline 76568 & SONIC CORP & 80432 & AMERICAN EAGLE OUTFITTERS INC N \\
\hline 76605 & AUTOZONE INC & 80670 & AIRTRAN HOLDINGS INC \\
\hline 76655 & TOYOTA MOTOR CORP & 80682 & FERRELLGAS PARTNERS L P \\
\hline 76671 & ANNTAYLOR STORES CORP & 80857 & VILLAGE SUPER MARKET INC A \\
\hline 76673 & RETAIL VENTURES INC & 80863 & NIPPON TELEGRAPH \& TELPHONE COR \\
\hline 76708 & DEVRY INC DEL & 80955 & WILLAMETTE VALLEY VINYDS INC \\
\hline 76750 & MONRO MUFFLER BRAKE INC & 81010 & STRATASYS INC \\
\hline 76760 & TELECOM CORPORATION NEW ZEALAND & 81042 & P T INDOSAT TBK \\
\hline 76795 & ZEBRA TECHNOLOGIES CORP A & 81049 & VINA CONCHA Y TORO S A \\
\hline 76847 & BON TON STORES INC & 81103 & ROYALE ENERGY INC \\
\hline 77186 & PERFUMANIA HOLDINGS INC & 81278 & STRATTEC SECURITY CORP \\
\hline 77281 & WHOLE FOODS MARKET INC & 81294 & WD $40 \mathrm{CO}$ \\
\hline 77453 & JACK IN THE BOX INC & 81481 & DOLLAR TREE INC \\
\hline 77462 & MACYS INC & 81521 & AMERIGAS PARTNERS LP \\
\hline 77516 & MENS WEARHOUSE INC & 81566 & P C MALL INC \\
\hline 77530 & STEIN MART INC & 81654 & BORDERS GROUP INC \\
\hline 77584 & BUCKLE INC & 81655 & DARDEN RESTAURANTS INC \\
\hline 77606 & KOHLS CORP & 81666 & HAWAIIAN HOLDINGS INC \\
\hline 77637 & FRANKLIN COVEY CO & 81669 & PORTUGAL TELECOM S G P S SA \\
\hline 77669 & FINISH LINE INC A & 81741 & SOCKET MOBILE INC \\
\hline 77702 & STARBUCKS CORP & 82518 & RICKS CABARET INTERNATIONAL INC \\
\hline 77902 & CHEESECAKE FACTORY INC & 82598 & NETAPP INC \\
\hline
\end{tabular}




\begin{tabular}{|c|c|c|c|}
\hline \multicolumn{4}{|c|}{ Table A 2 (Continued). Event Study Firms: Twitter } \\
\hline Permno & Firm & Permno & Firm \\
\hline 82618 & SANDISK CORP & 86209 & HASTINGS ENTERTAINMENT INC \\
\hline 82646 & PERUSAHAAN P P P T TELEKOM INDO & 86715 & CORINTHIAN COLLEGES INC \\
\hline 82720 & LEARNING TREE INTERNATIONAL INC & 86822 & EXTREME NETWORKS INC \\
\hline 82763 & XATA CORP & 86839 & OPTIBASE LTD \\
\hline 82830 & NICE SYSTEMS LTD & 86866 & TUESDAY MORNING CORP \\
\hline 83604 & S K TELECOM CO LTD & 86924 & THESTREET COM \\
\hline 83939 & HOT TOPIC INC & 86926 & TW TELECOM INC A \\
\hline 84062 & BJS RESTAURANTS INC & 87000 & STAMPS COM INC \\
\hline 84084 & HIBBETT SPORTS INC & 87043 & QUANTUM CORP \\
\hline 84157 & TERREMARK WORLDWIDE INC & 87054 & PETROHAWK ENERGY CORP \\
\hline 84203 & FAMOUS DAVES OF AMERICA & 87089 & SCIENTIFIC LEARNING CORP \\
\hline 84319 & LITHIA MOTORS INC & 87137 & DEVON ENERGY CORP NEW \\
\hline 84375 & TENNECO INC DE & 87251 & RADWARE LTD \\
\hline 84416 & COLDWATER CREEK INC & 87339 & PARTNER COMMUNICATIONS CO LTD \\
\hline 84555 & OVERLAND STORAGE INC & 87540 & PETROBRAS ENERGIA PARTICIPAC S \\
\hline 84588 & VAIL RESORTS INC & 88167 & HEALTHSTREAM INC \\
\hline 84621 & LOGITECH INTERNATIONAL SA & 88172 & KRISPY KREME DOUGHNUTS INC \\
\hline 85032 & QWEST COMMUNICATIONS INTL INC & 88309 & MOBILE TELESYSTEMS OJSC \\
\hline 85173 & COINSTAR INC & 88411 & TURKCELL ILETISIM HIZMETLERI A \\
\hline 85232 & B J S WHOLESALE CLUB INC & 88457 & NETWORK ENGINES INC \\
\hline 85333 & DOT HILL SYSTEMS CORP & 88494 & TATA COMMUNICATIONS LTD \\
\hline 85348 & YUM BRANDS INC & 88495 & ORIENT EXPRESS HOTELS LTD A \\
\hline 85390 & CHILDRENS PLACE RTL STORES INC & 88510 & CALIFORNIA PIZZA KITCHEN INC \\
\hline 85394 & PRICESMART INC & 88542 & LANTRONIX INC \\
\hline 85397 & RADCOM LTD & 88646 & STE C INC \\
\hline 85421 & CHINA MOBILE LTD & 88658 & TELUS CORP \\
\hline 85427 & GROUP 1 AUTOMOTIVE INC & 88779 & ICAD INC \\
\hline 85445 & INTERMEC INC & 88807 & NOVATEL WIRELESS INC \\
\hline 85452 & AC MOORE ARTS AND CRAFTS INC & 88888 & C NOOCLTD \\
\hline 85502 & IDENTIVE GROUP INC & 88976 & FISHER COMMUNICATIONS INC \\
\hline 85517 & CHOICE HOTELS INTERNATIONAL INC & 89016 & STATOILHYDRO A S A \\
\hline 85616 & LAN AIRLINES S A & 89030 & PRINCETON REVIEW INC \\
\hline 85726 & DENNYS CORP & 89099 & FALCONSTOR SOFTWARE INC \\
\hline 85886 & PC CONNECTION INC & 89110 & OMNICELL INC \\
\hline 85913 & MARRIOTT INTERNATIONAL INC NEW A & 89134 & ENCANA CORP \\
\hline 85914 & BEST BUY COMPANY INC & 89142 & SUREWEST COMMUNICATIONS \\
\hline 85939 & RED LION HOTELS CORP & 89217 & ADVANCE AUTO PARTS INC \\
\hline 85971 & PAETEC HOLDING CORP & 89289 & STAGE STORES INC \\
\hline 86128 & MARINEMAX INC & 89301 & GAMESTOP CORP NEW A \\
\hline 86150 & BEBE STORES INC & 89353 & JETBLUE AIRWAYS CORP \\
\hline
\end{tabular}




\begin{tabular}{|c|c|c|c|}
\hline \multicolumn{4}{|c|}{ Table A 2 (Continued). Event Study Firms: Twitter } \\
\hline Permno & Firm & Permno & Firm \\
\hline 89413 & BIG 5 SPORTING GOODS CORP & 91063 & VIACOM INC NEW B \\
\hline 89453 & RED ROBIN GOURMET BURGERS INC & 91068 & CHIPOTLE MEXICAN GRILL INC \\
\hline 89508 & CARMAX INC & 91081 & LINN ENERGY LLC \\
\hline 89617 & EQUINIX INC & 91096 & MORGANS HOTEL GROUP CO \\
\hline 89641 & SEAGATE TECHNOLOGY & 91099 & NTELOS HOLDINGS CORP \\
\hline 89644 & VIRGIN MEDIA INC & 91117 & MORTONS RESTAURANT GROUP INC NE \\
\hline 89704 & INTERCONTINENTAL HOTELS GRP PLC & 91151 & TIM HORTONS INC \\
\hline 89757 & SEARS HOLDINGS CORP & 91207 & STARWOOD HOTELS \& REST WLDWD IN \\
\hline 89778 & CHUNGHWA TELECOM CO LTD & 91237 & VONAGE HOLDINGS CORP \\
\hline 89813 & MEDCO HEALTH SOLUTIONS INC & 91262 & ATLAS AIR WORLDWIDE HOLDINGS IN \\
\hline 89896 & JO ANN STORES INC & 91354 & GOLFSMITH INTL HLDGS INC \\
\hline 89904 & BUFFALO WILD WINGS INC & 91376 & ATLAS PIPELINE HOLDINGS L P \\
\hline 89915 & MCGRATH RENTCORP & 91391 & WINDSTREAM CORP \\
\hline 89919 & PINNACLE AIRLINES CORP & 91416 & HANESBRANDS INC \\
\hline 89932 & KNOLOGY INC & 91507 & SUSSER HOLDINGS CORP \\
\hline 89973 & UNIVERSAL TECHNICAL INSTITUTE I & 91556 & ROSS STORES INC \\
\hline 90012 & PETMED EXPRESS INC & 91575 & HERTZ GLOBAL HOLDINGS INC \\
\hline 90187 & BLUE NILE INC & 91605 & CAPELLA EDUCATION CO \\
\hline 90209 & JACKSON HEWITT TAX SERVICE INC & 91624 & WINN DIXIE STORES INC \\
\hline 90242 & XYRATEX LTD & 91659 & ALLEGIANT TRAVEL CO \\
\hline 90248 & DOMINOS PIZZA INC & 91727 & TRAVELCENTERS AMERICA LLC \\
\hline 90286 & MCCORMICK \& SCHMICKS SEAFOOD RE & 91826 & U S AUTO PARTS NETWORK INC \\
\hline 90339 & INTEROIL CORP & 91888 & ARUBA NETWORKS INC \\
\hline 90346 & TATA MOTORS LTD & 91907 & SUPER MICRO COMPUTER INC \\
\hline 90371 & BUILD A BEAR WORKSHOP INC & 91926 & DELTA AIR LINES INC \\
\hline 90387 & NEW YORK \& CO INC & 91937 & METROPCS COMMUNICATIONS INC \\
\hline 90441 & NEWS CORP A & 91973 & ACORN INTERNATIONAL INC \\
\hline 90657 & VERIFONE HOLDINGS INC & 92177 & HHGREGG INC \\
\hline 90706 & CITI TRENDS INC & 92188 & WABCO HOLDINGS INC \\
\hline 90715 & ZUMIEZ INC & 92211 & VOLTAIRE LTD \\
\hline 90739 & PEOPLES EDUCATIONAL HOLDINGS IN & 92293 & TERADATA CORP DE \\
\hline 90742 & SILICON GRAPHICS INTL CORP & 92400 & LUMBER LIQUIDATORS INC \\
\hline 90793 & ROYAL DUTCH SHELL PLC B & 92449 & REEDS INC \\
\hline 90808 & EXPEDIA INC DE & 92454 & NEUTRAL TANDEM INC \\
\hline 90825 & A C C O BRANDS CORP & 92458 & CHINAEDU CORP \\
\hline 90865 & KONA GRILL INC & 92493 & $\mathrm{~K} 12 \mathrm{INC}$ \\
\hline 90896 & CARIBOU COFFEE CO INC & 92571 & LUCAS ENERGY INC \\
\hline 90969 & DOVER SADDLERY INC & 92618 & DR PEPPER SNAPPLE GROUP INC \\
\hline 90972 & JONES SODA CO & 92902 & BRIDGEPOINT EDUCATION INC \\
\hline 90983 & PEOPLES BANCORP NC INC NEW & & \\
\hline
\end{tabular}




\section{Appendix B}

\section{Robustness Checks}

A number of approaches can be taken when assessing abnormal returns during an event study. In the manuscript, we utilize a 4-factor model that incorporates a firm's sensitivity to market returns as well as market abnormalities related to market capitalization, book to market ratio (Fama and French 1996) and momentum (Carhart 1997). We also used an estimation window of 250 days (between days -280 and -30) stopping the estimation window 30 days before the event. However, an alternative approach is to set the estimation window between days to -251 and -1 . This can potentially provide different results since the estimation window ends 1 day prior to the event window. Table B1 shows the results from the 4factor model using a window of -250 and -1 .

Results are consistent with our original evaluation of Hypothesis 1 that included an estimation window from -280 and -30 . To analyze hypotheses Hypothesis 2 (i.e. innovator returns) and Hypothesis 3 (i.e. early adopter returns, we used equation 6 in the manuscript with the abnormal returns from the new estimation windows displayed above. Results from Table B2 confirm our original analysis results in which early adopters experience greater abnormal returns compared to later adopters of the technology.

Another potential approach from prior studies is to set an estimation window of 120 days (Dewan and Ren 2007; Subramani and Walden 2001). Using both the estimation windows used in the above analysis ( -121 , -1 and $-150,-30)$, results were consistent with overall abnormal returns for Facebook at 1.08\% $(C D A=2.78$, $p<0.01)$ and $1.08 \%(C D A=2.78, p<0.01)$ respectively for the windows. Twitter results were consistent as well with abnormal returns at $0.53 \%$ $(C D A=1.73, p<0.05)$ and $0.69 \%(C D A=1.94, p<$ 0.05). The subsequent regressions models also showed that for both Facebook and Twitter the Cumulative Abnormal Returns (CAR) were significant for Early Adopters and insignificant for Innovators across both estimation windows.

\section{Additional Robustness Check}

Prior literature has provided alternative approaches to the 4-factor model used in the current study.

Table B1. Abnormal Returns for 4-Factor Model

\begin{tabular}{|lllcl|}
\hline Sample & Sample Size & $\begin{array}{l}\text { Event } \\
\text { Window }\end{array}$ & MCAR & Portfolio Time-Series (CDA) \\
\hline Facebook & 243 & $(0,1)$ & $1.15 \%$ & $3.06^{* * *}$ \\
Twitter & 303 & $(0,1)$ & $0.65 \%$ & $1.95^{*}$ \\
\hline Notes: $* * * p<0.001, * * p<0.01,{ }^{*} p<0.05$, one-tail test. \\
\hline
\end{tabular}

Table B2: Cross-Sectional Generalized Least Squares Regression Models

\begin{tabular}{|l|ll|}
\hline \multicolumn{2}{|l|}{} & Dependent Variables \\
\cline { 2 - 3 } & \multicolumn{2}{|l|}{ Facebook CAR } \\
\hline Independent Variables & $4.82 \%(1.26)$ & \multicolumn{1}{l|}{ Twitter CAR } \\
\hline Intercept & $0.71 \%(0.42)$ & $0.28 \%(0.14)$ \\
Innovators (IN) & $2.08 \%^{*}(2.09)$ & $-0.30 \%(-0.26)$ \\
Early Adopters (EA) & $1.33 \%^{*}(2.24)$ \\
\hline Control Variables & $0.22 \%(-0.81)$ & $0.00 \%(-0.24)$ \\
\hline Firm Size (S) & $-5.30 \% \%^{* *}(-2.58)$ & $-5.53 \%^{*}(-2.28)$ \\
Return on Assets (ROA) & $-1.45 \%(-0.96)$ & $-2.24 \%^{*}(-2.28)$ \\
Leverage (LEV) & $0.00 \%(0.15)$ & $0.00 \%(-0.72)$ \\
Growth Opportunity (GROW) & $0.00 \%(0.67)$ & $0.00 \%(-0.29)$ \\
Selling Expenditures (SE) & \\
Industry (IND) - all industry dummy variables resulted in $\mathrm{p}>0.10$ & \\
\hline Notes: $* * * p<0.001, * * p<0.01,{ }^{*} p<0.05$, one-tail test. \\
t-values are in parentheses.
\end{tabular}


These approaches include the 3-factor model (market returns, market capitalization and book to market ration) (Fama and French 1996), the market model (Agrawal et al. 2006; Chatterjee et al. 2001; Ranganathan and Brown 2006) and the market adjusted model (Agrawal et al. 2006). To ensure results were consistent, analyses were run across all three of these benchmarks using both of the estimation windows used previously (i.e. $-250,-1$ \& $280,-30)$. The results were not sensitive to benchmarks used with statistical significance occurring across all three benchmarks for both estimation windows. Significance across the benchmarks was consistent for testing $\mathrm{H}_{2}$ and $\mathrm{H}_{3}$ using a cross-sectional GLS regression model for each benchmark.

\section{Appendix B References}

Agrawal, M., Kishore, R., and Rao, H. R. (2006). Market Reactions to E-Business Outsourcing Announcements: An Event Study, Information \& Management, 43(7), 861-873.
Carhart, M. M. (1997). On Persistence in Mutual Fund Performance, The Journal of Finance, 52(1), 57-82.

Chatterjee, D., Richardson, V., and Zmud, R. (2001). Examining the Shareholder Wealth Effects of Announcements of Newly Created Cio Positions, MIS Quarterly, 25(1), 43-70.

Dewan, S., and Ren, F. (2007). Risk and Return of Information Technology Initiatives: Evidence from Electronic Commerce Announcements, Information Systems Research, 18(4), 370-394.

Fama, E. F., and French, K. R. (1996). Multifactor Explanations of Asset Pricing Anomalies, The Journal of Finance, 51(1), 55-84.

Ranganathan, C., and Brown, C. V. (2006). ERP Investments and the Market Value of Firms: Toward an Understanding of Influential ERP Project Variables, Information Systems Research, 17(2), 145-161.

Subramani, M., and Walden, E. (2001). The Impact of E-Commerce Announcements on the Market Value of Firms, Information Systems Research, 12(2), 135-154. 